\title{
Pyroclastic density currents associated with the 2008-2009 eruption of Chaitén Volcano (Chile): Forest disturbances, deposits, and dynamics
}

\author{
Jon J. Major ${ }^{1}$, Thomas C. Pierson ${ }^{1}$, Richard P. Hoblitt ${ }^{1}$, Hugo Moreno ${ }^{2}$ \\ ${ }^{I}$ United States Geological Survey, Volcano Science Center, Cascades Volcano Observatory, 1300 SE Cardinal Court, Vancouver, \\ Washington 98683, USA. \\ jjmajor@usgs.gov; tpierson@usgs.gov;rhoblitt@usgs.gov \\ ${ }^{2}$ Servicio Nacional de Geología y Minería, Observatorio Volcanológico de Los Andes del Sur, Dinamarca 691, Temuco, Chile. \\ hmoreno@sernageomin.cl
}

\begin{abstract}
Explosive activity at Chaitén Volcano in May 2008 and subsequent dome collapses over the following nine months triggered multiple, small-volume pyroclastic density currents (PDCs). The explosive activity triggered PDCs to the north and northeast, which felled modest patches of forest as far as $2 \mathrm{~km}$ from the caldera rim. Felled trees pointing in the down-current direction dominate the disturbance zones. The PDC on the north flank of Chaitén left a decimeters-thick, bipartite deposit having a basal layer of poorly sorted, fines-depleted pumice-and-lithic coarse ash and lapilli, which transitions abruptly to fines-enriched pumice-and-lithic coarse ash. The deposit contains fragments of mostly uncharred organics near its base; vegetation protruding above the deposit is uncharred. The nature of the forest disturbance and deposit characteristics suggest the PDC was dilute, of relatively low temperature $\left(<200^{\circ} \mathrm{C}\right)$, and to first approximation had a dynamic pressure of about 2-4 $\mathrm{kPa}$ and velocity of about 30-40 $\mathrm{ms}^{-1}$. It was formed by directionally focused explosions through the volcano's prehistoric, intracaldera lava dome. Dilute, low-temperature PDCs that exited the caldera over a low point on the east-southeast caldera rim deposited meters-thick fill of stratified beds of pumice-and-lithic coarse ash and lapilli. They did not fell large trees more than a few hundreds of meters from the caldera rim and were thus less energetic than those on the north and northeast flanks. They likely formed by partial collapses of the margins of vertical eruption columns. In the Chaitén River valley south of the volcano, several-meterthick deposits of two block-and-ash-flow (BAF) PDCs are preserved. Both have a coarse ash matrix that supports blocks and lapilli predominantly of lithic rhyolite dome rock, minor obsidian, and local bedrock. One deposit was emplaced by a BAF that traveled an undetermined distance downvalley between June and November 2008, apparently triggered by partial collapse of a newly effused lava dome that started growing on 12 May. A second, and larger, BAF related to another collapse of the new lava dome on 19 February 2009 traveled to within $3 \mathrm{~km}$ of the village of Chaitén, $10 \mathrm{~km}$ downstream of the volcano. It deposited as much as 8-10 $\mathrm{m}$ of diamict having sedimentary characteristics very similar to the previous BAF deposit. Charred trees locally encased within the BAF deposits suggest that the flows were of moderate temperature, perhaps as much as $300^{\circ} \mathrm{C}$. Erosion of the BAF deposits filling the Chaitén River channel has delivered substantial sediment loads downstream, contributing to channel instability and challenged river management.
\end{abstract}

Keywords: Chaitén Volcano, Pyroclastic density current, Directed explosions, Dome collapse, Block-and-ash flow, Dynamic pressure, Flow velocity, Temperature. 
RESUMEN. Flujos piroclásticos asociados a la erupción 2008-2009 del volcán Chaitén: perturbación del bosque, depósitos y dinámica. La actividad explosiva del volcán Chaitén ocurrida en mayo de 2008, y los posteriores colapsos del domo ocurridos en los nueve meses siguientes, provocó múltiples flujos piroclásticos de pequeño volumen. Esta actividad explosiva gatilló flujos hacia el norte y noreste que derribaron algunos retazos de bosque incluso a una distancia de $2 \mathrm{~km}$ desde el borde de la caldera. Troncos quebrados que se orientan en la dirección de flujo dominan las zonas de perturbación. El flujo piroclástico del flanco norte generó un depósito de algunos decímetros de espesor compuesto de dos niveles: una capa basal de lapilli y ceniza gruesa pumícea y lítica mal seleccionada, empobrecida en material fino, que transita abruptamente a un segundo nivel de ceniza gruesa pumíceo-lítica enriquecida en finos. Cerca de su base, el depósito contiene fragmentos de materia orgánica mayoritariamente sin carbonizar mientras que la vegetación que sobresale de él exhibe la misma característica. El tipo de perturbación observado en el bosque y las características del depósito, sugieren que el flujo fue diluido, de temperatura relativamente baja $\left(<200^{\circ} \mathrm{C}\right)$, y que habría ejercido una presión dinámica de alrededor de 2-4 $\mathrm{kPa}$ con una velocidad de aproximadamente 30-40 $\mathrm{ms}^{-1}$. Este flujo piroclástico se habría formado como resultado de explosiones dirigidas a través del domo prehistórico. A su vez, los flujos piroclásticos diluidos y de baja temperatura que abandonaron la caldera a través de la escotadura situada al este-sureste de ella, generaron un depósito de espesor métrico bien estratificado y formado por capas de lapilli y ceniza gruesa de pómez y líticos. Estos flujos no derribaron árboles más allá de algunos cientos de metros desde el borde de la caldera y se infiere, por lo tanto, que fueron menos energéticos que aquellos del flanco norte y noreste. Probablemente, estos flujos se generaron por colapso parcial desde los márgenes de columnas eruptivas verticales. En el valle del río Chaitén, al sur del volcán, se han reconocido dos depósitos de 'bloques y ceniza' de varios metros de espesor. Ambos tienen una matriz de ceniza gruesa que contiene bloques y lapilli lítico de composición riolítica provenientes del domo, y en menor proporción obsidiana y fragmentos líticos del basamento local. Uno de estos depósitos fue generado por un flujo de tipo 'bloques y ceniza' que viajó una distancia indeterminada valle abajo entre junio y noviembre de 2008, al parecer provocado por el colapso parcial del domo que comenzó a crecer el 12 de mayo. Un segundo y mayor flujo de este tipo, relacionado con otro colapso del domo ocurrido el 19 de febrero de 2009 , alcanzó hasta menos de $3 \mathrm{~km}$ de la localidad de Chaitén, $10 \mathrm{~km}$ aguas abajo del volcán. Este último generó un depósito de hasta 8-10 m de un diamicto con características sedimentarias muy similares al anterior. Los árboles localmente carbonizados incluidos en los depósitos de 'bloques y ceniza' sugieren que los flujos fueron de temperatura moderada, tal vez no superior a $300^{\circ} \mathrm{C}$. La erosión de estos depósitos en valle del río Chaitén suministra una carga considerable de sedimento aguas abajo, lo que aumenta la inestabilidad del cauce y constituye un desafío para el manejo del mismo.

Palabras clave: Volcán Chaitén, Flujos piroclásticos, Explosiones dirigidas, Colapso de domo, Flujo de 'bloques y ceniza', Presión dinámica, Velocidad de flujo, Temperatura.

\section{Introduction}

One of the largest recent eruptions in South America, and one of the few rhyolite eruptions of the past 100 years, occurred in 2008-09 at Chaitén Volcano in southern Chile (Fig. 1). Chaitén consists of a rhyolite dome complex nestled within a $3-\mathrm{km}$ diameter caldera. Before the 2008-09 eruption, the caldera contained a $\sim 500$ million $\mathrm{m}^{3}$ prehistoric lava dome (Pallister et al., 2013, this volume). The eruption began late on 1 May 2008 (local time UTC-4) with minor ash emissions, which were followed shortly by a Plinian eruption column that rose to a height greater than $20 \mathrm{~km}$ (Carn et al., 2009; Lara, 2009; Major and Lara, 2013, this volume). Vigorous explosions continued intermittently through 8 May 2008, after which explosive activity waned; new effusive dome growth, simultaneous with explosive activity, began around 12 May (Basualto et al., 2008; Folch et al., 2008; Carn et al., 2009; Lara, 2009; Alfano et al., 2011; Castro et al., 2012; Pallister et al., 2013, this volume). Despite a propensity for rhyolite eruptions to produce voluminous and widespread pyroclastic density currents (PDCs) (e.g., Walker, 1980; Bacon, 1983; Wilson, 1985; Hildreth and Fierstein, 2000), only small PDCs having limited impact near the volcano were generated by the explosive phase of the Chaiten eruption. These PDCs were confined mainly to the north, east, and east-northeast flanks of the volcano within 2-3 $\mathrm{km}$ of the caldera rim. Partial collapses of

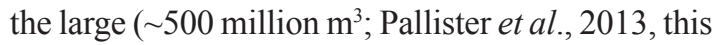
volume) new lava dome between June and November 2008 and again in February 2009 triggered additional PDCs to the south of the volcano in the Chaitén River valley, and one of those traveled approximately $6 \mathrm{~km}$ beyond the caldera rim.

Small PDCs (those inundating up to about 10 $\mathrm{km}^{2}$ and having volumes $<10^{6}-10^{7} \mathrm{~m}^{3}$ ) can have significant environmental and social impacts (e.g., Blong, 1984; Sigurdsson et al., 1984; Miyabuchi, 1999; Abdurachman et al., 2000; Loughlin et al., 2002; Sparks et al., 2002; Baxter et al., 2005; Cole 


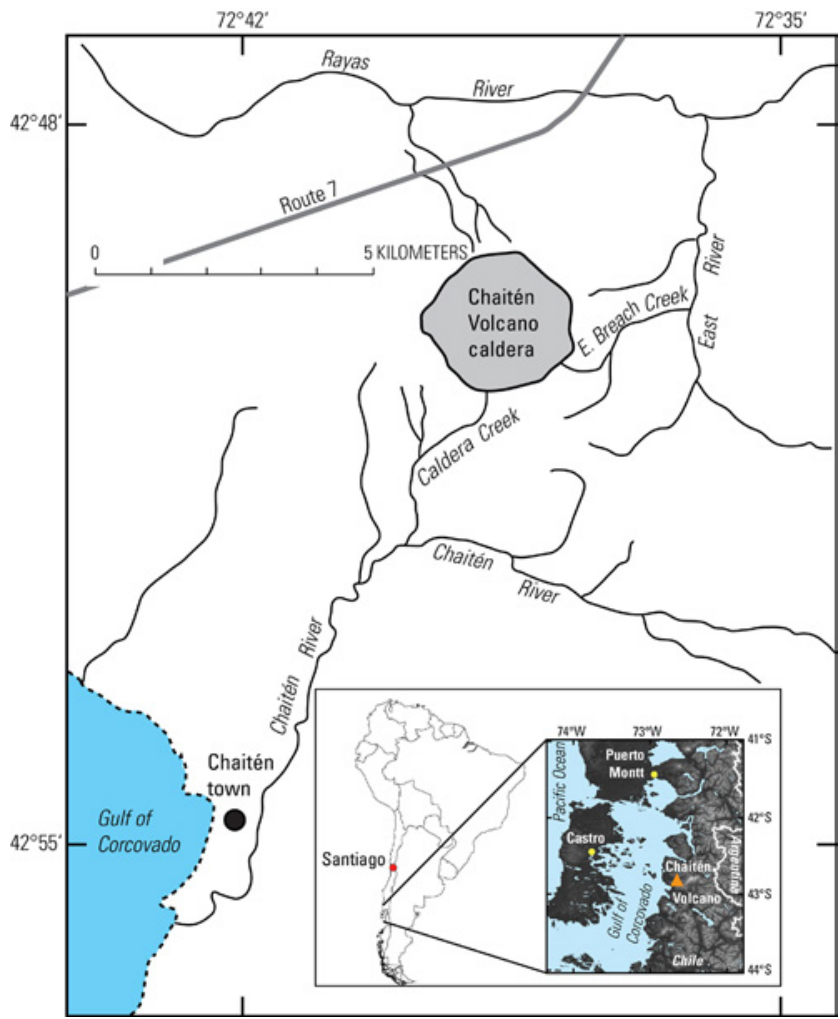

FIG. 1. Location map of Chaitén Volcano. The volcano is located in southern Chile along the Andean Southern Volcanic Zone on the northern end of the Andean Patagonia region. The small port town of Chaitén is located $10 \mathrm{~km}$ south of the center of the volcano. Route 7, the major land link north of the volcano, passes within $2 \mathrm{~km}$ of the caldera rim. et al., 2005; García et al., 2011; Sarocchi et al., 2011; Charbonnier and Gertisser, 2011). Although the PDCs generated by the explosive phase of the eruption of Chaitén Volcano significantly affected the forested flanks of the volcano, and the dome-collapse PDC in February 2009 traveled to within $3 \mathrm{~km}$ of the coastal town of Chaitén (Fig. 1), they had no direct impact on communities or infrastructure. However, secondary processes following the PDCs and erosion of their deposits damaged local infrastructure and delivered substantial sediment loads to the major rivers draining the volcano, which has contributed to channel instability and challenged river management.

In this paper, we examine the impacts of PDCs on the forest and the nature of their deposits on the north, east, and south sides of the volcano in order to constrain their emplacement times, determine emplacement processes, and quantify flow dynamics. We show that the PDCs were generated by a variety of mechanisms, which left distinctive signatures in their deposits. Helicopter-supported reconnaissance field work in the Chaitén River valley began in 2010, after 1-2 seasons of austral winter high flows had eroded and reworked deposits, and the lower to middle reaches of the valley were revisited on foot in 2011 and 2012. Field work on the north side of the volcano was conducted on foot in 2010 and 2011. Remote and rugged terrain inhibited access to the east-northeast side of the volcano, although one of us (R. Hoblitt) conducted a brief helicoptersupported reconnaissance in that sector.

\section{Overview of eruption activity}

The eruption of Chaitén Volcano began late on 1 May 2008 (local time) with minor ash emissions that followed about 24 hours of felt earthquakes (Castro and Dingwell, 2009) and a M3.5 earthquake, tentatively located about $15 \mathrm{~km}$ north of Chaitén town, which may have signaled the onset of eruption (Basualto et al., 2008; Major and Lara, 2013, this volume). The first Plinian eruption began shortly thereafter at approximately 0800 UTC (0400 local time) on 2 May, and lasted about 6-8 hours (Carn et al., 2009; Major and Lara, 2013, this volume). This opening phase of activity included at least two PDCs, because video footage from a commercial aircraft (Aerotaxis del Sur) around noon on 2 May (E. Hein 
Bahamonde, written communication, 2012) shows PDCs descending the north-northwest and possibly the east-northeast flanks. Sustained tephra emissions with eruption columns rising 10-20 km continued until 6 May when a second energetic explosion sent an eruption column to an altitude of about $20 \mathrm{~km}$ (Folch et al., 2008; Durant et al., 2012; Major and Lara, 2013, this volume). That explosion was followed by at least two additional energetic bursts of activity over the next 8 hours (Folch et al., 2008). A third Plinian eruption occurred on 8 May (Carn et al., 2009; Major and Lara, 2013, this volume) during poor weather. Limited visual observations late in the afternoon suggest a PDC moved into the valley east of the volcano (which we informally call East River valley; Fig. 1) (SERNAGEOMIN, 2008b). From 8-12 May, explosive activity waned. Seismic data suggest effusive activity began about 12 May (Basualto et al., 2008; Carn et al., 2009; Lara, 2009), although growth of a new dome was not confirmed until 21 May (SERNAGEOMIN, 2008d). Extraordinarily rapid effusion ( $\sim 45 \mathrm{~m}^{3} \mathrm{~s}^{-1}$ average) of lava during the first four months of eruption extruded nearly 500 million $\mathrm{m}^{3}$ of crystal-poor, high-silica $\left(75 \% \mathrm{SiO}_{2}\right)$ rhyolite that largely covered the old lava dome (Pallister et al., 2010; 2013, this volume). Minor collapses and rockfalls from the new lava dome produced deposits of talus and minor pyroclastic flows within the volcano's caldera (Pallister et al., 2013, this volume), but between June and November 2008 and again on 19 February 2009 substantial collapses of the lava dome produced PDCs that exited the caldera, the latter of which (Fig. 2) traveled about $6 \mathrm{~km}$ beyond the caldera rim along the Chaitén River valley (Fig. 1).

Tephra falls from the explosive phase of the eruption are widespread, and several fall layers mantle

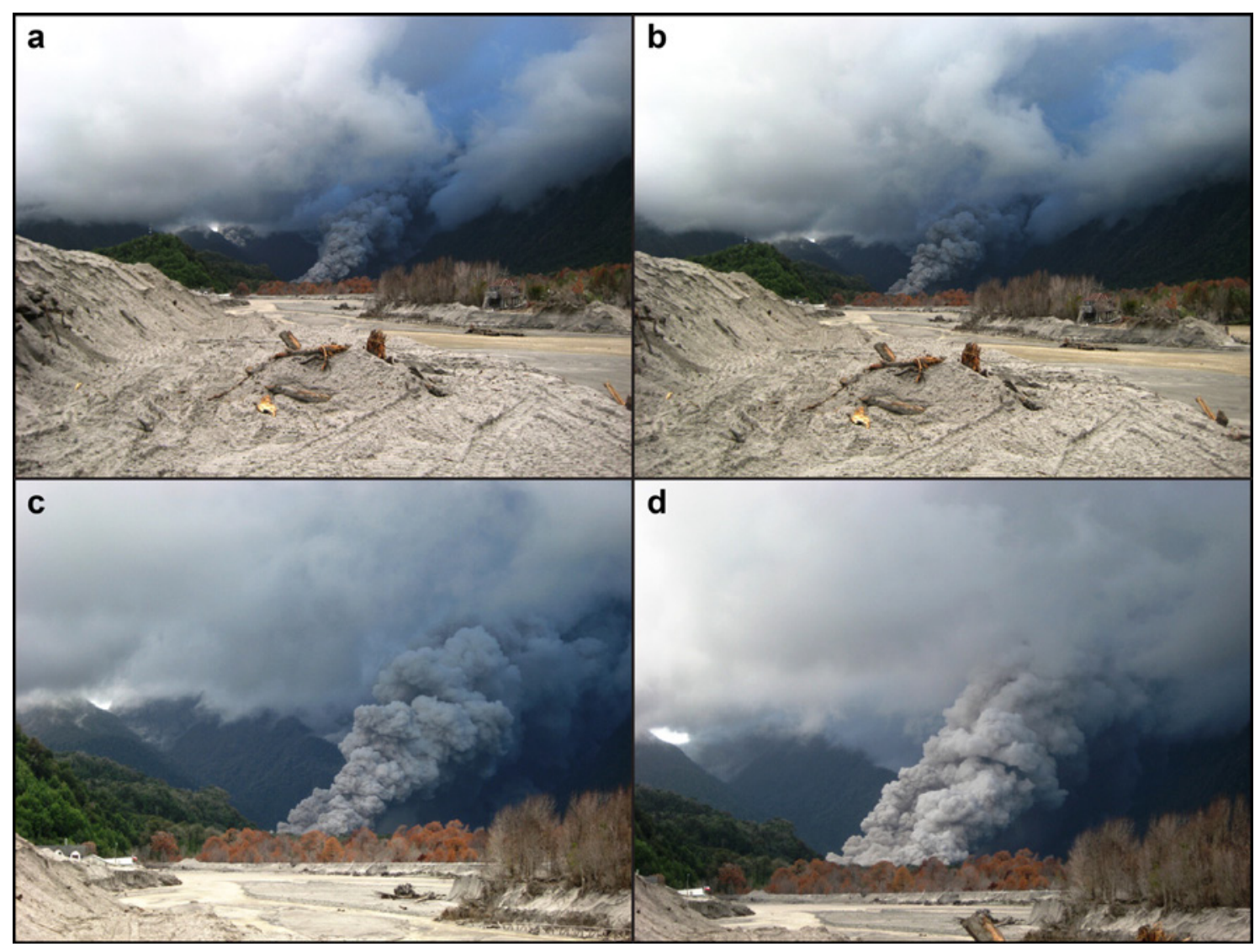

FIG. 2. Photographs of pyroclastic density current (PDC) in Chaitén River valley on 19 February 2009. View is looking upstream from bridge in Chaitén town. a. 10:42 am; b. 10:43 am; c. 10:43 am; d. 10:44 am. Note the changes in focal length among the images. Images courtesy of Dagoberto Guzman, Parque Pumalín. Used with permission. 
the topography near Chaitén. Alfano et al. (2011) describe sequences of tephra falls to the northeast, east, and southeast of Chaitén Volcano, which are related to various phases of the eruption and influenced by dominant wind directions (Table 1). To the southeast of the volcano at sites 15 to $20 \mathrm{~km}$ from the vent, they describe a sequence of well-sorted, coarse (about $1 \mathrm{~mm}$ ) to extremely fine $(<0.063 \mathrm{~mm}$ ) ash layers (layers A-O), which they infer fell predominantly from 3-5 May. Layers A-J, generally gray in color, fell mainly to the southeast of the caldera, whereas layers K-M, which are pink to white-gray, and layers $\mathrm{N}$ and $\mathrm{O}$, which are gray, fell predominantly east. The earliest fall deposit to the north-northeast is layer $\alpha$, which consists of buff-colored fine ash containing lithic lapilli to several mm. Alfano et al. (2011) correlate this fall with the initial Plinian event on 2 May. The thickest, and most distinctive, fall layer to the north-northeast, the $\beta$ layer, consists of lapilli (as large as $60 \mathrm{~mm}$ within $5 \mathrm{~km}$ of the vent; Alfano et al., 2011) composed of approximately $80 \%$ lithic fragments, $10 \%$ obsidian, and $10 \%$ pumice. The lithic fragments are dominantly foliated fresh rhyolite, but are also composed of a minor proportion of oxidized (red) rhyolite. This deposit has been correlated with the climactic explosive phase on 6 May. Layers $\chi-\pi$ form a sequence of deposits characterized by alternating layers of gray to white fine ash and fine lapilli, and are thought to represent very-low volume explosive activity, and perhaps minor collapses of the lava dome, between 7 May 2008 and January 2009 (Alfano et al., 2011).

\section{Pyroclastic density currents: forest disturbance and deposits}

The explosive phase of the eruption and subsequent dome collapses triggered multiple PDCs. Small-volume $\left(10^{5}-10^{6} \mathrm{~m}^{3}\right)$ PDCs affected the north and east-northeast sides of the volcano. To the south of the volcano in the Chaitén River valley, we find no definitive evidence of a PDC associated with the explosive phase of the eruption. Instead, we find one pumice-bearing ash-and-lapilli deposit of ambiguous origin deposited during the explosive phase of eruption, and deposits of small-volume PDCs associated with later dome collapses. In addition, the Chaitén River valley was severely affected by a rainfall-triggered 'lahar-flood' as the explosive phase of activity waned (Pierson et al., 2013). For- est disturbances and deposits of the PDCs affecting the north, east, and south sides of the volcano are described.

\subsection{North side of Chaitén Volcano}

The Chaitén Volcano caldera sits atop an eastsouthwest trending ridge having about $600-800 \mathrm{~m}$ of local relief above valley floors (e.g., see Major and Lara, 2013, this volume). Outer slopes are generally straight to concave upward. The steep $(\sim 0.33 \mathrm{~m} / \mathrm{m})$, dissected north flank of the volcano extends about 1.3 $\mathrm{km}$ from the caldera rim (elevation $700-750 \mathrm{~m}$ ) to a flatter gradient $(\sim 0.09 \mathrm{~m} / \mathrm{m})$ fan that locally bounds the south side of the Rayas River valley (fan head elevation $\sim 200 \mathrm{~m}$ ) (Figs. 1, 3, 4). Several-meter-deep channels dissect the fan and provide pathways for debris flows and floods. Horizontal distances from the caldera rim to the fan head, and from the fan head to the Rayas River are similar (Fig. 4).

The PDC on the north side of the volcano had the most striking visual impact because it felled a patch of forest partly visible from Route 7, the national highway leading north from Chaitén town, which passes within $2 \mathrm{~km}$ of the caldera rim (Figs. 1, 3). Stratigraphic evidence shows only one PDC deposit on the north side of the volcano, and its extent is largely bounded by the felled forest and an adjacent singe zone. Although not visible from the road, a small patch of forest on the east-northeast flank was also felled by a PDC (Fig. 4).

\subsubsection{Forest disturbance on the north side of Chaitén Volcano}

The PDC that swept the north flank of Chaitén Volcano felled about $4 \mathrm{~km}^{2}$ of forest, extending about $2 \mathrm{~km}$ from the caldera rim to Route 7 (Figs. 3, 4). Felled trees are oriented in the down-current direction (Fig. 4). Near the caldera rim, the PDC largely removed the canopy from felled trees and standing snags and swept some trees farther downslope. It also removed the understory. Shallow landslides swept many felled trees into proximal channels, giving the appearance that the PDC had removed many trees near the rim. The distal limit of forest disturbance is characterized mainly by minor tree abrasion and foliage kill (Fig. 4) (Swanson et al., 2013, this volume). Felled trees were mostly uprooted rather than broken above ground level (e.g., Figs. 5a, d, f; $6 \mathrm{a}, \mathrm{b}$ ), although many broken trees are present. 
TABLE 1. TEPHRA FALL LAYERS ASSOCIATED WITH THE EXPLOSIVE PHASE OF THE 2008-2009 ERUPTION OF CHAITÉN VOLCANO (ADAPTED FROM ALFANO ET AL., 2011).

\begin{tabular}{|c|c|c|c|c|}
\hline $\begin{array}{l}\text { Tephra } \\
\text { layer }\end{array}$ & $\begin{array}{l}\text { Primary } \\
\text { sector }\end{array}$ & $\begin{array}{l}\text { Dominant } \\
\text { color }\end{array}$ & Composition $^{1}$ & $\begin{array}{c}\text { Inferred } \\
\text { emplacement date }\end{array}$ \\
\hline A & SE & gray white & coarse ash, $60 \%$ pumice, average grain size $1 \mathrm{~mm}$ & 3-5 May 2008 \\
\hline B & SE & gray & fine to coarse ash, lithic rich & 3-5 May 2008 \\
\hline $\mathrm{C}$ & SE & white & coarse ash, pumice rich & 3-5 May 2008 \\
\hline $\mathrm{D}$ & SE & gray & fine to coarse ash & 3-5 May 2008 \\
\hline $\mathrm{E}$ & SE & white & coarse ash, pumice rich & 3-5 May 2008 \\
\hline $\mathrm{F}$ & SE & gray & fine ash & 3-5 May 2008 \\
\hline G & SE & light gray & fine ash grading up to coarse ash & 3-5 May 2008 \\
\hline $\mathrm{H}$ & SE & gray & coarse ash & 3-5 May 2008 \\
\hline I & SE & white & coarse ash & 3-5 May 2008 \\
\hline $\mathrm{J}$ & SE & gray & fine ash & 3-5 May 2008 \\
\hline $\mathrm{K}$ & E & pink & fine ash & 3-5 May 2008 \\
\hline $\mathrm{L}$ & E & gray to white & fine banded ash & 3-5 May 2008 \\
\hline M & E & pink & fine massive ash with discontinuous gray layers & 3-5 May 2008 \\
\hline $\mathrm{N}$ & E & light gray & fine ash & after 5 May 2008 \\
\hline $\mathrm{O}$ & $\mathrm{E}$ & dark gray & reworked ash & after 5 May 2008 \\
\hline $\mathrm{P}$ & $\mathrm{S}$ to $\mathrm{E}$ & gray white & scattered pumice lapilli on surface & after 5 May 2008 \\
\hline$\alpha$ & $\mathrm{NE}$ & buff brown & ash with lithic fragments at base & 1-2 May 2008 \\
\hline$\beta$ & NNE & mixed & lapilli; $80 \%$ lithic & 6 May 2008 \\
\hline$\chi$ & $\mathrm{N}$ to $\mathrm{E}$ & gray & fine ash & 7 May 2008-Jan 2009 \\
\hline$\delta$ & $\mathrm{N}$ to $\mathrm{E}$ & white & coarse ash, pumice rich & 7 May 2008-Jan 2009 \\
\hline$\varepsilon$ & $\mathrm{N}$ to $\mathrm{E}$ & gray & fine ash & 7 May 2008-Jan 2009 \\
\hline$\psi$ & $\mathrm{N}$ to $\mathrm{E}$ & white & coarse ash, pumice rich & 7 May 2008-Jan 2009 \\
\hline$\gamma$ & $\mathrm{N}$ to $\mathrm{E}$ & gray & fine ash & 7 May 2008-Jan 2009 \\
\hline$\eta$ & $\mathrm{N}$ to $\mathrm{E}$ & gray white & coarse ash and lapilli, $60-70 \%$ pumice & 7 May 2008-Jan 2009 \\
\hline 1 & $\mathrm{~N}$ to $\mathrm{E}$ & gray & fine ash & 7 May 2008-Jan 2009 \\
\hline$\varphi$ & $\mathrm{N}$ to $\mathrm{E}$ & white & coarse ash and lapilli & 7 May 2008-Jan 2009 \\
\hline$\kappa$ & $\mathrm{N}$ to $\mathrm{E}$ & gray & fine ash & 7 May 2008-Jan 2009 \\
\hline$\lambda$ & $\mathrm{N}$ to $\mathrm{E}$ & gray white & coarse ash and lapilli, $50 \%$ pumice, $50 \%$ lithic & 7 May 2008-Jan 2009 \\
\hline$\mu$ & $\mathrm{N}$ to $\mathrm{E}$ & gray & fine ash & 7 May 2008-Jan 2009 \\
\hline$v$ & $\mathrm{~N}$ to $\mathrm{E}$ & white black & coarse ash with obsidian lithics & 7 May 2008-Jan 2009 \\
\hline$v^{*}$ & $\mathrm{~N}$ to $\mathrm{E}$ & white & coarse ash and lapilli & 7 May 2008-Jan 2009 \\
\hline o & $\mathrm{N}$ to $\mathrm{E}$ & gray & fine ash & 7 May 2008-Jan 2009 \\
\hline$\rho$ & $\mathrm{N}$ to $\mathrm{E}$ & brown & fine ash & 7 May 2008-Jan 2009 \\
\hline$\theta$ & $\mathrm{N}$ to $\mathrm{E}$ & gray & fine ash & 7 May 2008-Jan 2009 \\
\hline$\pi$ & $\mathrm{N}$ to $\mathrm{E}$ & white gray & scattered pumice lapilli on surface & 7 May 2008-Jan 2009 \\
\hline
\end{tabular}

${ }^{1}$ The compositions of layers A-O are from a section measured $19.5 \mathrm{~km}$ downwind from the volcano. The compositions of layers $\alpha-\pi$ are from a section measured $11.1 \mathrm{~km}$ downwind (see Alfano et al., 2011 figures 2 and 3). 


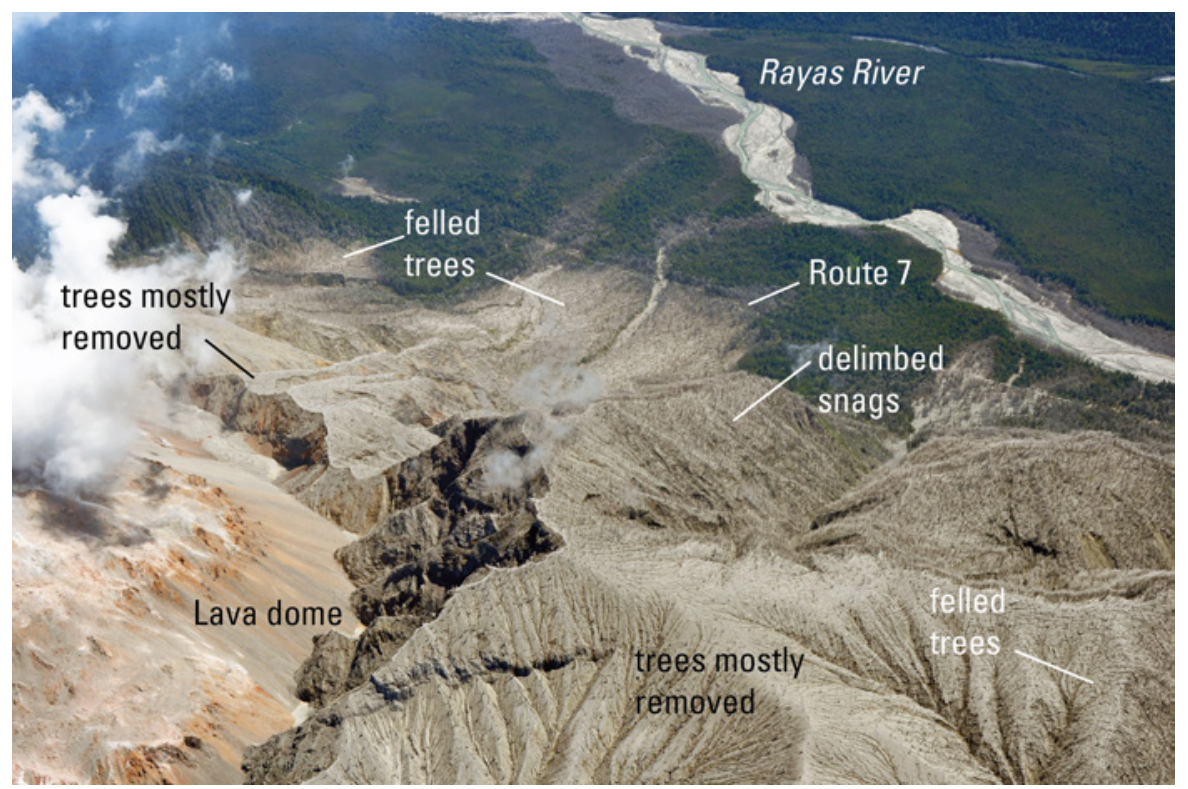

FIG. 3. Oblique aerial view to the northwest of the north side of Chaitén Volcano showing forest disturbance caused by the 2008-2009 eruption. Distance from caldera rim to Rayas River is about $3 \mathrm{~km}$. The image shows zones of dominant tree removal and tree felling, small channels affected by debris flows, and forest stripped by heavy tephra fall (delimbed snags) (see figure 4; also see Swanson et al., 2013, this volume). Photograph by John Pallister, United States Geological Survey, 24 January 2010.

Those trees that were broken remain as standing delimbed snags (Figs. 5c, e; 6a, d). Although the PDC swept across the landscape and locally surmounted ridges, it was partly funneled into channels leading from the rim and largely guided by local topography (Fig. 4). In contrast, the PDC that felled trees along the east-northeast flank of the volcano swept along hillslope contour before descending down the slope gradient (Fig. 4).

The extent of structural damage to vegetation decreases with distance from the caldera rim. It is greatest within about $750 \mathrm{~m}$ (horizontal distance). To that distance, denuded standing snags as large as $1 \mathrm{~m}$ diameter are shattered or deeply abraded (Fig. 5a, c), canopy has been swept away, and meter-diameter felled trees have tens-ofcentimeters-thick PDC deposit lapped against vent-facing rootwads (Fig. 5a, c). On the lee side of a ridge oriented approximately transverse to flow direction, many delimbed snags remain, but they have been snapped off at a consistent level about 10-15 m above ground (Fig. 5c, e), suggesting that part of the PDC detached from the ground as it swept over the ridge crest. To a distance of about $1.5 \mathrm{~km}$, many felled trees had their limbs and canopy structure removed and swept away before and during felling (e.g., Figs. 5d; 6a, b), and much of the bamboo understory was removed or substantially crushed (Fig. 6a, b). At greater distance, many felled trees retain their upper limbs and fine branches, and dense understory remains in growth position between and beneath felled trees, increasing in density downslope (Fig. 6c).

Bark damage beyond about $1.3 \mathrm{~km}$ from the caldera rim was much less extensive on felled trees than on standing snags (Fig. 6b, d). Although lianas (climbing plants entwined around trees) on vent-facing sides of felled trees had been removed, bark remained largely intact. In contrast, standing snags displayed variable bark removal. Some had all of their bark removed, most had bark abraded off the vent-facing side, and others had little bark removed. In general, most standing snags had bark abraded off their vent-facing sides typically to a height of at least $15 \mathrm{~m}$. Standing snags shorter than 15-m tall were abraded along their entire length, whereas taller snags exhibited both full abrasion and some intact bark above $15 \mathrm{~m}$. The degree of bark removal appeared to be species dependent. Ulmo (Eucryphia cordifolia) had typically lost 


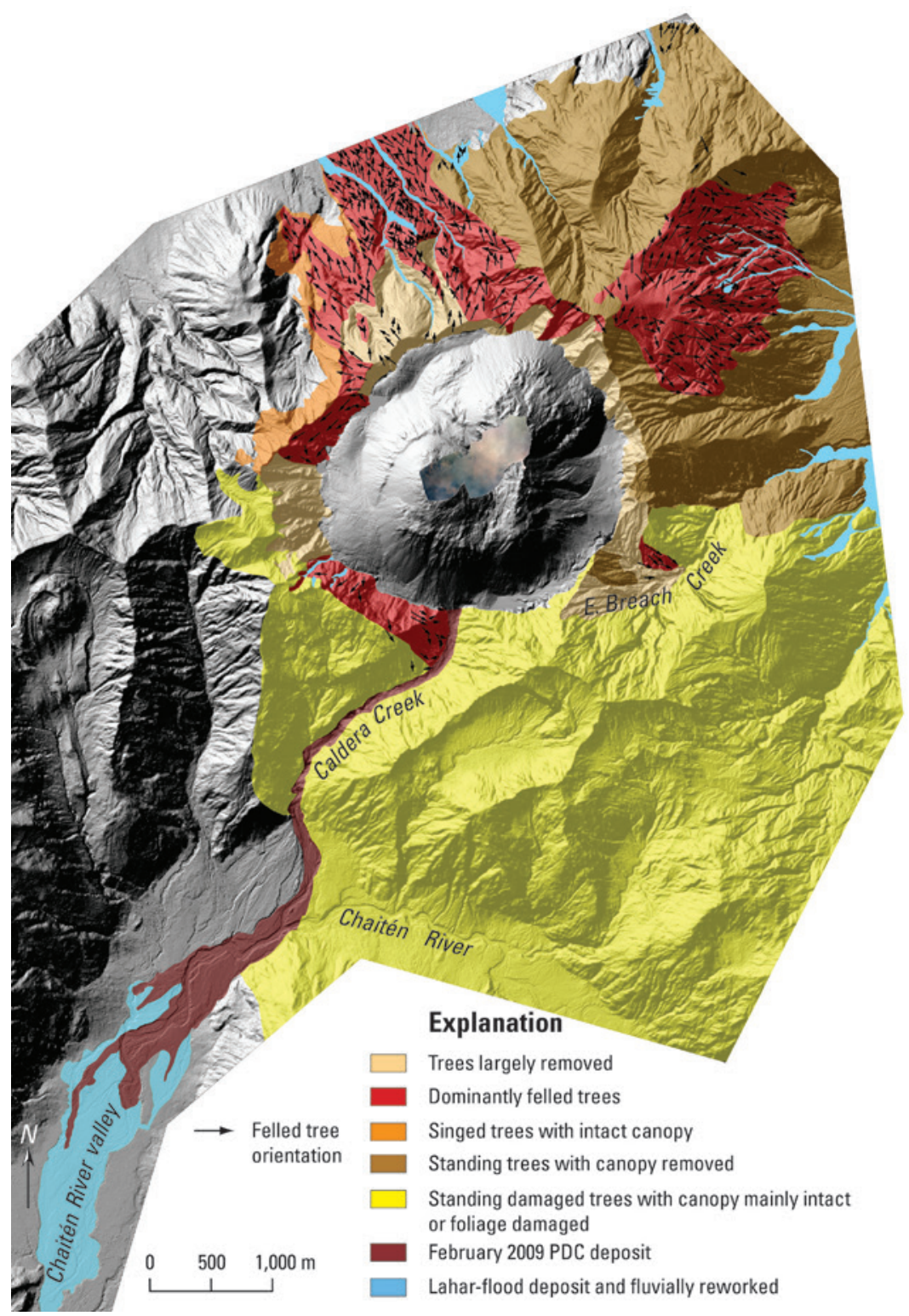

FIG. 4. Photo-interpretation of forest damage zones at Chaitén Volcano superposed on a lidar-derived digital elevation model. Arrows indicate orientation of felled trees. See figure 3 for oblique aerial view of damage on north side of volcano. Base map is compiled from lidar surveys conducted by Digimapas Chile between 15 October and 7 December 2009 and provided by the Regional Government of Los Lagos region. Map has $1 \mathrm{~m}$ resolution and uses UTM zone 18 South projection. The horizontal datum is WGS84.

all bark, which was partly related to decomposition after mortality (Swanson et al., 2013, this volume), whereas Coihue (Nothofagus dombeyi and Nothofagus nitida) and Tineo (Weinmannia trichosperma) typically had bark stripped from only the vent-facing sides (Fig. 6d) or had little removed. Wood beneath removed bark was not deeply abraded, but instead showed largely uniformly dispersed percussion marks along the height of a snag; percussion mark density and intensity are not obviously graded (Fig. 6d, e). Large rock fragments embedded in snags are rare but locally notable (Swanson et al., 2013, this volume). No felled trees or standing snags were charred, and even most fine twigs, leaves, and roots of lianas were uncharred.

\subsubsection{Pyroclastic density current deposit on north side of Chaitén voclano}

The PDC on the north side of Chaitén Volcano deposited a coarsely stratified bipartite layer mainly of pumice-and-lithic coarse to very coarse ash and lapilli (grain size terminology follows White and Houghton, 2006). At the caldera rim, the deposit 


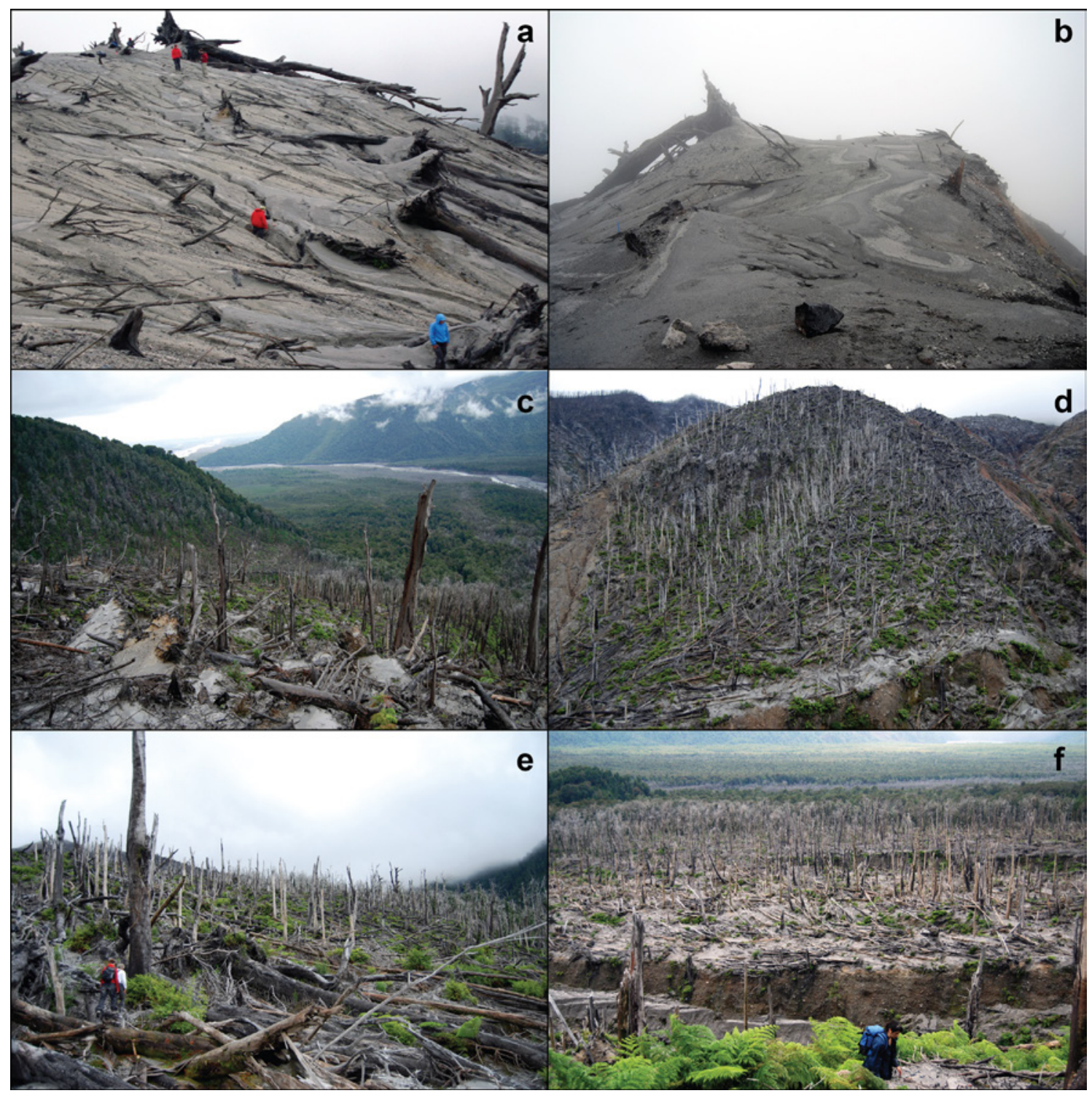

FIG. 5. Photographs of tree damage on north side of Chaitén Volcano. a. View of tree damage at north rim of caldera. Photograph by Fred Swanson, United States Forest Service; b. View of tree damage at north rim of caldera; c. Downslope view to northwest of felled trees and standing snags on north flank about $500 \mathrm{~m}$ from rim. Note how PDC deposit laps onto rootwads of felled trees; d. Upslope view of felled trees and standing snags about $1 \mathrm{~km}$ from rim where steep outer flank on north side of volcano emerges onto flatter open area; e. Upslope view of standing snags on north flank in lee of ridge about $1 \mathrm{~km}$ from caldera rim. Note the uniform level at which snags are broken, and people for scale; f. Downslope view to northeast of felled trees and standing snags on north flank about $1.3 \mathrm{~km}$ from rim. Note that snags in foreground are shattered. Note person for scale. All photographs taken 21 January 2011.

thickness exceeds $1 \mathrm{~m}$, but it rapidly thins to $40 \mathrm{~cm}$ or less on the upper flank about 10-15 m below the rim. Locally, it thins over topographic rises, and along its extent the deposit laps onto the vent-facing sides of rootwads of felled trees. Beyond the break in slope $1.3 \mathrm{~km}$ from the caldera rim the deposit typically ranges from a few $\mathrm{cm}$ to a few tens of $\mathrm{cm}$ thick, but atypical thicknesses locally approach a meter. This highly variable thickness owes mainly to the presence of felled trees impounding deposit 


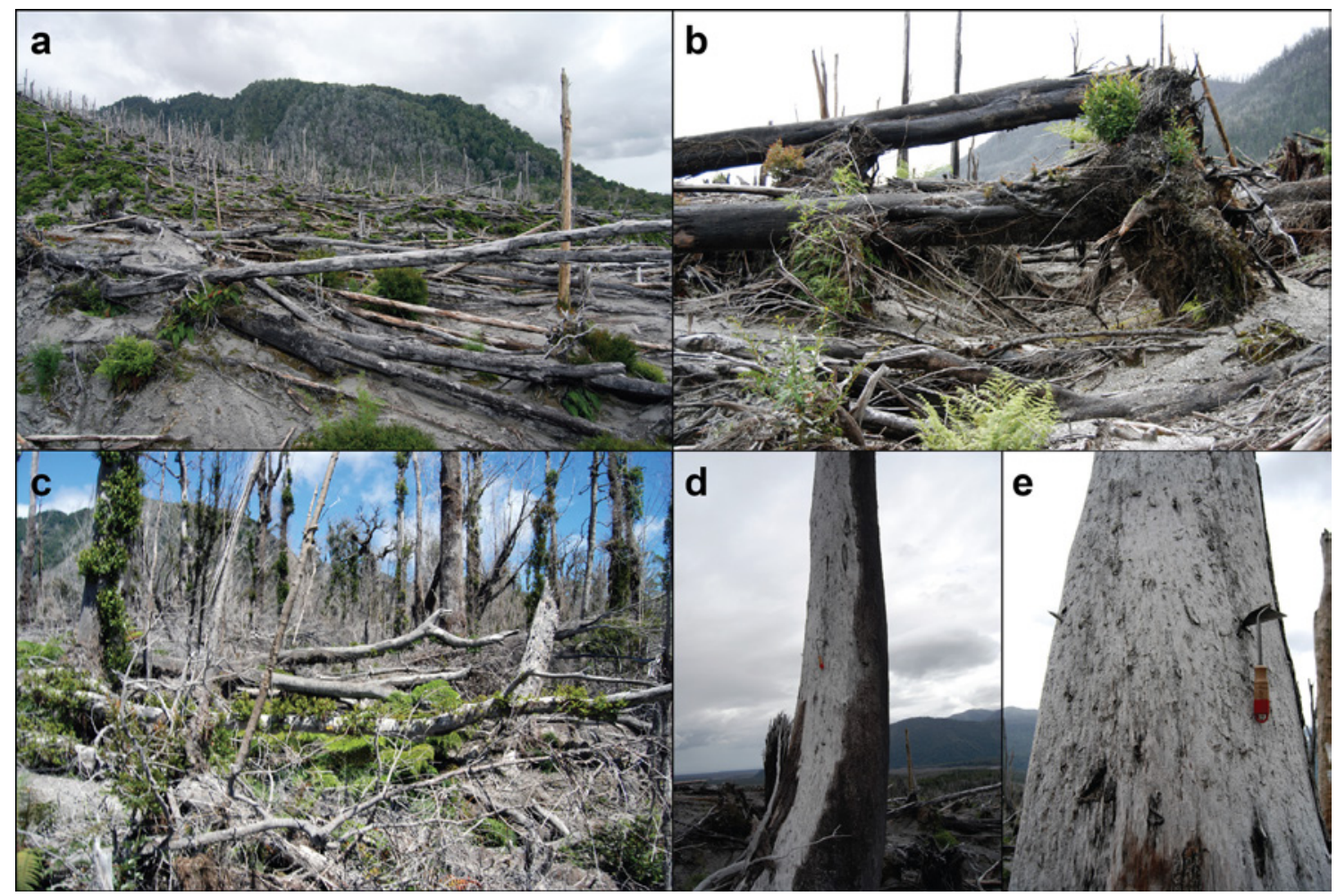

FIG. 6. Photographs of tree damage on north side of Chaitén Volcano. a. Felled trees near break in slope about $1 \mathrm{~km}$ from caldera rim. Note that felled trees are missing their limb network and that bamboo understory is largely removed; b. Felled trees about $1.5 \mathrm{~km}$ from caldera rim in central part of felled tree zone. Note that felled trees are largely uprooted rather than snapped; c. Forest damage near distal end of disturbed area about $1.8 \mathrm{~km}$ from caldera rim. Note that standing snags and felled trees largely retain limb structure, and understory vegetation is mostly intact; d, e. Abrasion of wood on vent-facing sides of standing snags about $1.4 \mathrm{~km}$ from caldera rim. Note that wood is relatively lightly, and uniformly, abraded along length of snag. Scraper is $25 \mathrm{~cm}$ long. Photographs taken in January 2011.

on vent-facing sides. In general, the deposit is thin to absent beneath felled trees showing that trees were felled prior to significant sediment deposition. The deposit covers an area of about $4 \mathrm{~km}^{2}$, and has a bulk volume of about $0.5-1 \times 10^{6} \mathrm{~m}^{3}$ [0.0005-0.001 $\mathrm{km}^{3}$ ]. It can be broadly divided into two facies: a lower, friable, fines-depleted, lapilli-rich facies and an upper, ash-rich facies (Fig. 7).

3.1.2.1. Lower facies. The lower facies of the PDC deposit is composed of friable, poorly sorted, fines-depleted, pumice-and-lithic very coarse ash and fine-medium lapilli (Figs. 7a-c). Beyond the caldera rim to a distance of at least $1.5 \mathrm{~km}$, facies thickness is generally about 15 to $20 \mathrm{~cm}$, but varies locally from a few $\mathrm{cm}$ to $50 \mathrm{~cm}$. Lapilli are composed of both pumice and lithic fragments. Pumice and subpumice (density $>1,000 \mathrm{kgm}^{-3}$; e.g., Alfano et al,
2012) lapilli are angular and mostly less than or equal to $1 \mathrm{~cm}$ diameter, although some are as large as $10 \mathrm{~cm}$. Lithic lapilli are also angular, but typically are smaller. Most lithic lapilli are less than $5 \mathrm{~mm}$ in diameter and rarely as large as $5 \mathrm{~cm}$. The largest lapilli and small blocks are predominantly angular pumice. The facies has a grain-supported texture with voids common between grains, and typically is massive, but locally exhibits slight normal or inverse grading of the larger clasts. The mean grain size of five spatially distributed samples of this facies ranges from 1.6-2.7 $\mathrm{mm}$ (very coarse ash), and only $0.5-1.5 \%$ of the deposit is composed of particles finer than $0.063 \mathrm{~mm}$ (extremely fine ash). The facies has a sorting coefficient of about $2.0 \varphi$, indicative of its poor sorting (Folk, 1980).

Particle composition of the lower facies is locally variable, but overall is comprised of about 
$50 \%$ pumice and subpumice, $40 \%$ lithic fragments, and $10 \%$ obsidian. Pumice fragments are typically white, elongate to equant, and have a fibrous texture; subpumice fragments are grayish white. Lithic fragments include both dense and vesicular gray rhyolite, banded rhyolite, oxidized (red) rhyolite, and minor quantities of basement bedrock.

Organic material within the facies, composed of twigs, leafs, and fragments of shredded tree bark and bamboo, is predominantly uncharred. Partially to completely charred organic material predominates in rare thick (many tens of $\mathrm{cm}$ ) sections of deposit. Entrained organic material is concentrated near the base of the facies, but some is locally dispersed throughout its thickness. Within a km of the caldera rim, minor mixing of soil in the basal few $\mathrm{cm}$ of the deposit, which locally imbues it with an orange-brown tint, provides evidence of soil erosion; beyond this distance the basal contact is largely conformable with the forest floor, although local erosion is observed.

\subsubsection{Upper facies. The upper facies of the PDC} deposit is finer grained and generally more lithicrich than the lower facies. It is composed mainly of poorly to very poorly sorted medium-coarse to coarse ash and fine lapilli (Figs. 7a, b, d); particles larger than $10 \mathrm{~mm}$ are rare, but lapilli to $5 \mathrm{~mm}$ are common and are matrix supported. Mean grain size of four samples of this facies varies from 0.6-0.9 mm (coarse ash), and the content of extremely fine ash varies from $2-10 \%$. Sorting coefficients of samples range from $1.9-2.9 \varphi$. This facies is generally massive. It is much less friable than the lower facies, and slightly cohesive when damp. It is generally about 5 to $10 \mathrm{~cm}$ thick, but locally is as thick as $20 \mathrm{~cm}$. The contact between the facies is abrupt but transitional, and the upper facies typically composes about a third of total deposit thickness. Sampling of both facies was insufficient to detect any systematic spatial variations in size or sorting over the short distance of deposition. The composition of the upper facies varies locally, but overall is comprised of about $30 \%$ pumice and subpumice, $60 \%$ lithic fragments, and $10 \%$ obsidian. The pumice and lithic compositions of this facies are similar to those of the lower facies. In contrast to the lower facies, the upper facies is mostly devoid of detrital organic matter.

3.1.2.3. Overlying deposits. The PDC deposit is sharply overlain by various thin $(1 \mathrm{~mm}-5 \mathrm{~cm})$ lay- ers of fine to medium-coarse ash having a variety of hues. At the rim, the PDC deposit is overlain by at least five of these ash layers, which include gray to slightly pink fine ash, olive-yellow to olive-brown fine ash, and well-sorted, very coarse ash and fine lapilli composed of pumice and lithic fragments. Beyond a $\mathrm{km}$ from the caldera rim, the PDC deposit is locally overlain by similar layers, although not all of those observed at the rim are found (Figs. 7a, b, d). Of particular note is a thin, dark-yellow-brown fine ash that locally overlies the PDC deposit (Fig. 7d). Angular fragments of pumice and aphyric gray rhyolite, commonly 2-3 $\mathrm{cm}$ in diameter, are dispersed atop the surface of these ash layers.

The PDC deposit is not found outside the boundary of felled and singed trees. Within undamaged forest immediately west of the main patch of felled trees, $3-5 \mathrm{~cm}$ of gray, fine to medium-fine ash, interpreted to be tephra fall, directly overlies the forest floor and the PDC deposit is absent. Hence, the PDC deposit is unequivocally related to the event that felled trees and is not a thick, proximal tephra fall. Furthermore, it is the only primary flowage deposit observed on the north flank of the volcano. The deposit has been eroded and reworked locally by fluvial runoff and debris flows.

\subsubsection{Interpretation and timing of pyroclastic density current on north side of Chaitén Volcano}

The nature of the proximal forest disturbance caused by the north-side PDC at Chaitén Volcano, and its deposit, are similar to disturbances and deposits of PDCs documented at Lamington, Bezymianny, Arenal, Mount St. Helens, Soufrière Hills Volcano, and Merapi (Taylor, 1958; Hoblitt et al., 1981; Waitt, 1981; Kelfoun et al., 2000; Ritchie et al., 2002; Alvarado et al., 2006; Belousov et al., 2007). However, the PDCs at all but Merapi were attributed to directed volcanic blasts (Hoblitt et al., 1981; Ritchie et al., 2002; Alvarado et al., 2006; Belousov et al., 2007; Belousova et al., 2011). Those eruptions generated violent, vertically and longitudinally stratified pyroclastic density currents triggered by rapid unloading of a shallow magma body as a result of sector failure or dome collapse. No sector failure or dome collapse occurred during the explosive phase of eruption at Chaitén, yet its north-side deposit is remarkably similar to those from directed volcanic blasts. In each of those other 
a

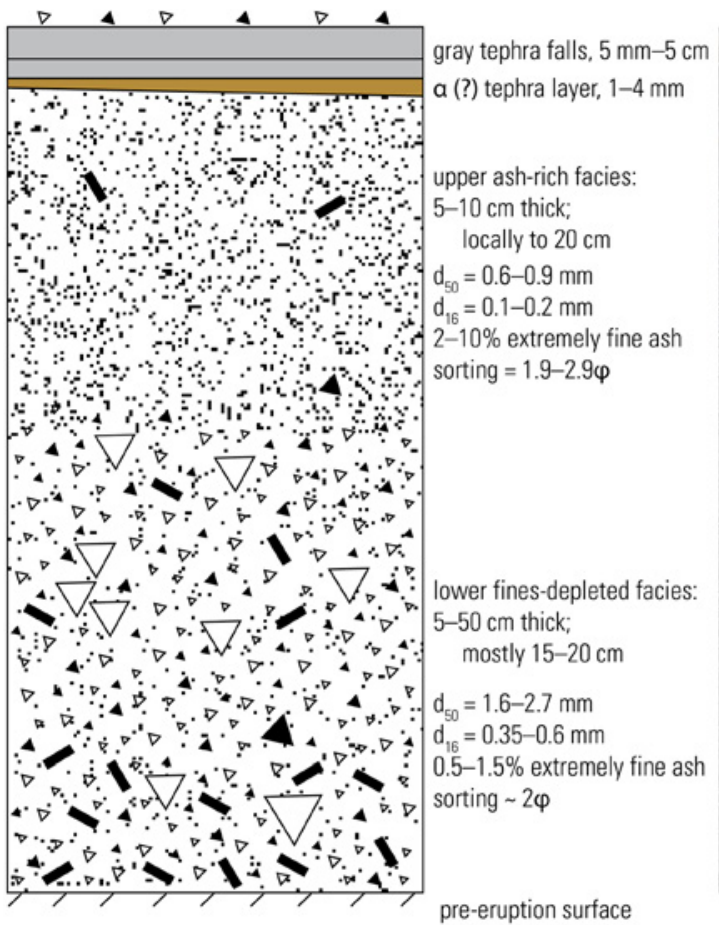

b

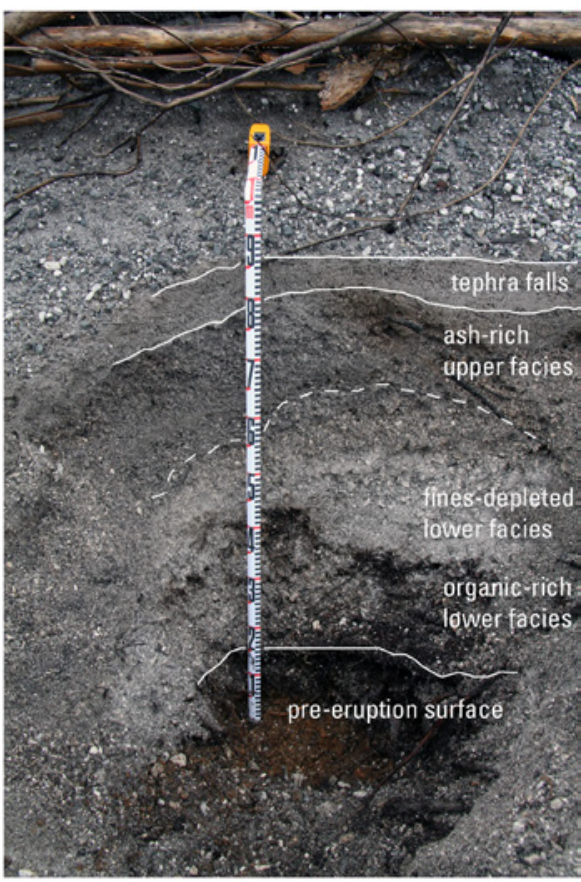

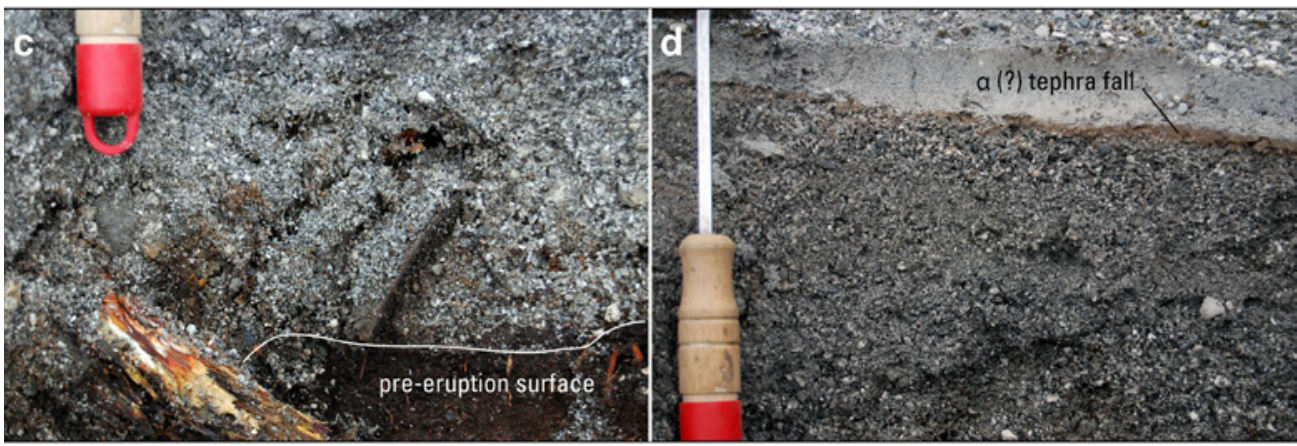

$\nabla$ angular pumice lapilli

A angular lithic lapilli

organic debris, locally charred

FIG. 7. PDC-deposit facies on north side of Chaitén Volcano about $1.5 \mathrm{~km}$ from caldera rim. a. Schematic stratigraphic sketch of deposit (not to scale); b. Photograph of atypically thick section of entire deposit. Numerical scale in decimeters; c. Close up view of lower facies of deposit. Note sharp contact with underlying forest floor, and minor scour and mixing of substrate into deposit; d. Close up view of upper facies of deposit. Note the more ash-rich, finer-grained texture of this facies compared to the lower facies, and the overlying tephra falls. Thin, yellow-brown tephra fall is inferred to be the $\alpha$-layer identified by Alfano et al. (2011). Scraper handle about $2 \mathrm{~cm}$ wide.

cases, juvenile material composes $50 \%$ or more of the deposits, and proximal stratigraphy commonly comprises a four-layer sequence (Belousov et al., 2007), although layers are deposited neither uniformly nor ubiquitously. Generalized descriptions (from bottom to top) and emplacement-process interpretations of those layers are as follows (Belousov et al., 2007):

- Basal layer A consists of very poorly sorted, typically ungraded debris, commonly ash and 
lapilli, mixed with vegetation and soil, and has a strongly erosive basal contact. It is typically enriched in material eroded from the substrate. Commonly, the layer is fines-depleted and friable. Plant fragments can be uncharred or partly charred. It reflects intense, turbulent boundary shear between the basal part of the energetic head of the PDC and the substrate.

- Layer B consists of relatively well-sorted, strongly fines-depleted lapilli with some charred plant fragments. It typically has a clast-supported fabric with open voids between clasts, and is thus very friable. Unlike layer A, there is generally little substrate material admixed in this layer except for local entrainment of vegetation. Most vegetation is found in the basal third of the deposit. The layer can display variable grading or be massive and ungraded. It represents suspension sedimentation under rapidly waning, high-sediment-concentration conditions.

- Layer C is chiefly a massive, poorly sorted, matrix-supported layer enriched in fine ash. Commonly, its uppermost part is laminated, and the layer can exhibit structured bedforms such as dunes. It is inferred to result from rapid sedimentation under moderate-concentration, tractive conditions.

- The uppermost layer D consists mainly of very fine ash and accretionary lapilli resulting from fallout of the finest particles from a high-rising, buoyant, thermal plume derived from the sedimentdepleted PDC (Hoblitt, 2000).

Belousov et al. (2007) draw analogy to laboratory experiments with aqueous density currents to conceptualize the emplacement mechanics of blast PDCs. By analogy, mixing at the head of the PDC with ambient fluid (in this case air) creates a turbulent wake above the body of a gravity-driven current. Layers A and B are inferred to be deposited by the flow body, and layer $\mathrm{C}$ by the wake. Layer $\mathrm{D}$ is more likely to be produced by large blast events or voluminous ignimbrites (Brown et al., 2010) rather than by small-magnitude PDCs. However, accretionary lapilli have been documented in deposits of small-magnitude PDCs (e.g., Fujii and Nakada, 1999), especially those that entered bodies of water (e.g., Cole et al., 2002; Ritchie et al., 2002).

The PDC deposit on the north side of Chaitén Volcano is most similar to layers B (Chaitén lower facies) and $\mathrm{C}$ (Chaitén upper facies) described by
Belousov et al. (2007). Although the Chaitén PDC was not strongly erosive except near the caldera rim and locally on the steep outer flank, its deposit exhibits local mixing of soil and vegetation near its base, so that layer A of Belousov et al. (2007) is locally present (Fig. 7b), but here mostly contiguous with layer B.

The fine ash layers overlying the PDC deposit are interpreted as tephra falls from the explosive phase of the eruption. Tephra-fall deposits described by Alfano et al. (2011) and visual observations are used to constrain the emplacement time of the PDC deposit. The pink hues of some tephras overlying the PDC deposit near the north caldera rim, perhaps tephras K-M (Alfano et al., 2011; Table 1), suggest the PDC occurred early in the eruption sequence, perhaps no later than 5 May. On the north-flank fan, we observed about 1-4 mm of dark-yellow-brown, fine to extremely fine ash locally overlying the PDC deposit (Fig. 7d). If that ash is the $\alpha$ tephra fall (Table 1), then its stratigraphic position indicates that the PDC was emplaced during the initial explosive phase on 2 May (Alfano et al., 2011). Video by Aerotaxis del Sur at about noon on 2 May (E. Hein Bahamonde, written communication, 2012) shows a PDC descending the north flank, consistent with observed stratigraphic relations. Furthermore, only one PDC deposit has been identified on the north side of the volcano. The gray tephra fall deposits lying atop the yellow-brown ash further confirm that the PDC had occurred by 7 May, as those layers are most likely correlated with the A-J, N-O, or $\chi-\pi$ sequences of Alfano et al. (2011), which all fell mainly between 3-7 May (Table 1). Servicio Nacional de Geología y Minería (SERNAGEOMIN) observers report notable damage to the north-flank forest on 12 May (SERNAGEOMIN, 2008c). We therefore know that the PDC occurred prior to that date. Although poor weather precluded many observation flights during the first week of eruption, reports from observation flights to the northwest side on 3 May and 6 May make no mention of such damage, but hazy and cloudy conditions may have inhibited clear views. Although the stratigraphy suggests that the PDC possibly occurred as early as 2 May, and video shows an early-stage PDC on the north-northwest flank, the notable absence of any mention of obvious forest disturbance in SERNAGEOMIN information reports until 12 May casts some ambiguity on the precise timing of the event. Nevertheless, stratigraphy and early visual 
observations indicate that the PDC occurred early in the explosive phase of eruption.

\subsection{East side of Chaitén Volcano}

Deposit stratigraphy within the caldera moat and forest disturbance on the east flank of the volcano show that PDCs swept through the east part of the caldera and down the east flank. Inferences of the occurrence of PDCs drawn from stratigraphy and forest disturbance are bolstered by eyewitness observations of small PDCs descending the east flank during the first week of eruption (SERNAGEOMIN, 2008b). Furthermore, a modest patch of forest was felled on the outer northeast flank (Fig. 4), similar to the forest disturbance that occurred on the north side of the volcano.

\subsubsection{Deposits of pyroclastic density currents in the eastern moat of the caldera}

Large-scale dune structures (Fig. 8a) were encountered during a brief helicopter-assisted reconnaissance of the eastern caldera moat in January 2010. Dunes on the caldera floor are composed of stratified sequences (Fig. 8b) of beds of friable, grain-supported lapilli of white pumice and gray subpumice, salt-and-pepper-colored beds of white pumice and dark gray lithic lapilli and coarse ash, fine-grained cohesive beds of gray ash, and poorlysorted beds of faintly-stratified ash and polymictic lapilli supporting angular lithic blocks as much as 1-2 decimeters. Beds are laterally discontinuous and bedding is curviplanar.

Similar stratified beds were recognized in outcrops at the low point on the east-southeast caldera rim, at the head of the drainage we informally call East Breach Creek (Fig 1). The stratified beds are collectively more than 2 meters thick; the base of this unit is covered. On the basis of similar compositions and stratigraphic sequencing, we correlate these stratified beds with the large-scale dunes encountered in the eastern moat. These stratified beds are overlain by a massive, poorly-sorted, moderately cohesive ash-and-lapilli unit up to two meters thick (Fig. 9a). Lapilli and rare blocks are angular and exhibit a range of vesicularities from light-gray subpumice to black obsidian; subpumice is the most abundant type. The location of this outcrop of stratified beds at the head of East Breach Creek suggests that the flow(s) that formed the large-scale dunes on the caldera floor traveled some distance down the drainage below the caldera rim. This suggestion is strengthened by the presence of broken and abraded trees in the upper drainage, just below the caldera rim (Fig. 9b). These trees are uncharred.

\subsubsection{Deposit of pyroclastic density current near the confluence of East Breach Creek and East River}

A brief helicopter-assisted reconnaissance of the area around the confluence of East Breach Creek and East River (Fig. 1) revealed deposits of reworked tephra fall as well as candidate PDC deposits. This site is about $3 \mathrm{~km}$ east of the caldera rim.

Thick sediment fill accumulated at the lower end of East Breach Creek and in East River during and immediately following the explosive phase of eruption. Terraces as much as $15 \mathrm{~m}$ high are present along East Breach Creek and East River near their confluence (Fig 10a). The terrace deposits are composed of massive to faintly horizontally stratified beds of pumice-rich sand and fine gravel supported in a siltysand matrix. Locally interspersed within the section are horizontally stratified to cross-stratified beds of pumice-rich sand and fine gravel with weak to sharp contacts between beds. Bed thicknesses range from about one millimeter to as much as several meters thick. Vegetation buried by the deposits is uncharred. These deposits temporarily filled the East Breach Creek and East River channels near the confluence, but they were subsequently dissected, leaving high terraces along both sides of the channels.

Above the high terrace on the north side of the confluence of East Breach Creek, the forest initially appeared to be damaged mainly by tephra fall. Large trees were standing and unabraded, but largely delimbed, liana stems and tree bark were largely intact and uncharred, and small understory trees were broken. Although heavy tephra fall certainly caused some of the tree damage (Swanson et al., 2013, this volume), closer inspection of tree damage suggested passage of a PDC. Broken understory trees had their tops pointed downhill (Fig. 10b), and ash clung to tree trunks at a consistent height above the ground. These disturbances suggested passage of a laterally moving current rather than vertical tephra fall. Ash clung to tree trunks to about 8 to $10 \mathrm{~m}$ above the ground surface, but the site was too far above East Breach Creek to have been affected by deep aqueous flows. Furthermore, the generally wet climate and crusting of intact deposit surfaces suggest that 


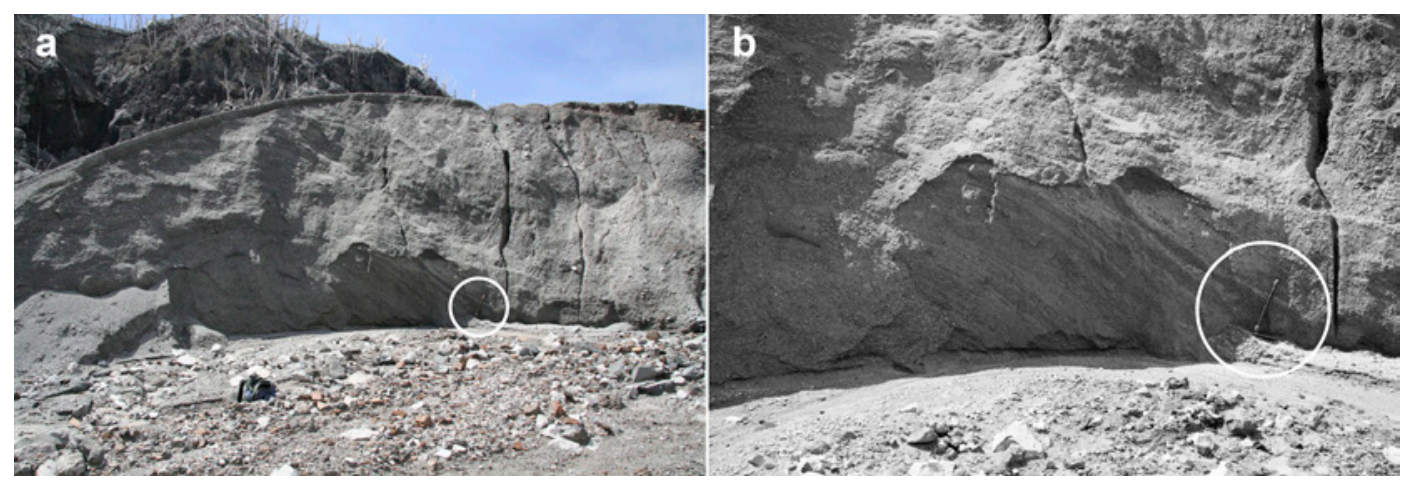

FIG. 8. Photographs of dune deposit in east caldera moat. a. Outcrop of dune deposit. Note the curviplanar surface of the dune; b. Close up view of outcrop showing stratified beds. Shovel handle (circled) is about $45 \mathrm{~cm}$ long.
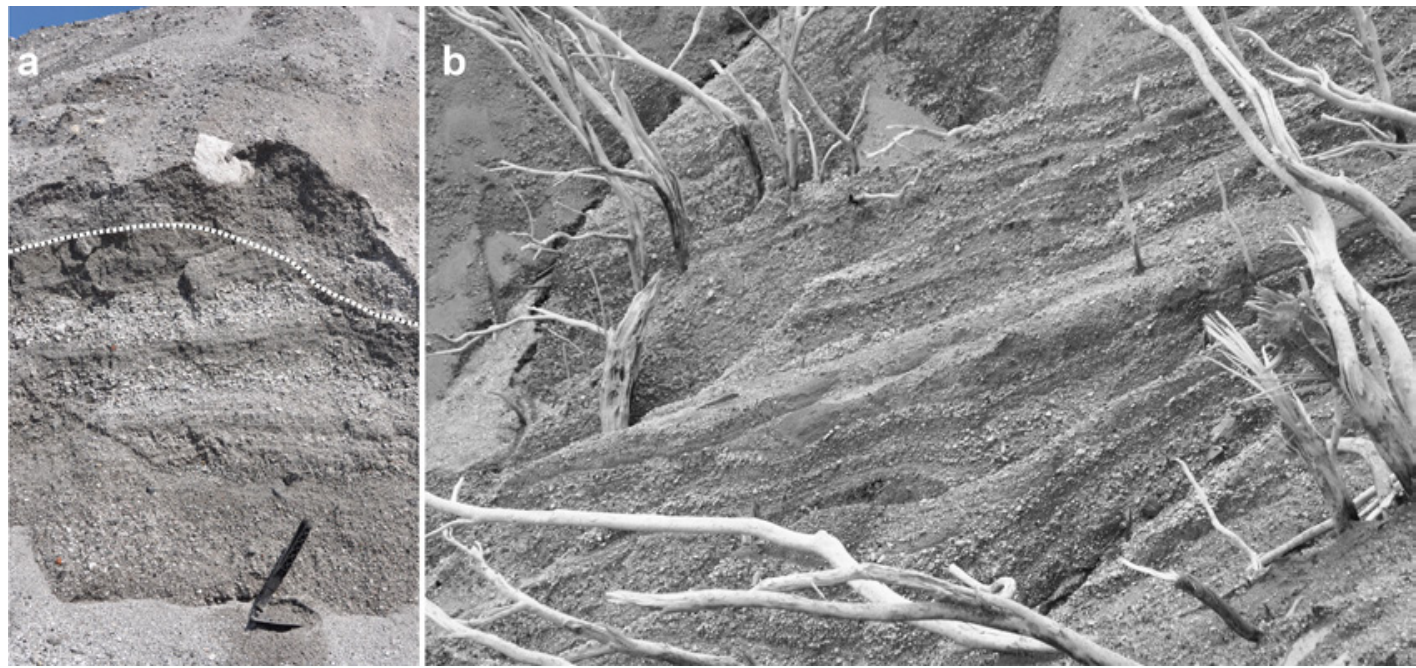

FIG. 9. Photographs of PDC deposits in southeast moat of caldera and tree disturbance on upper east flank of Chaitén Volcano. a. Photograph of outcrop in the east-southeast moat of caldera. Stratified beds within a dune bedform (below dashed line) are overlain by a massively textured pyroclastic-flow deposit. Shovel handle is about $45 \mathrm{~cm}$ long; $\mathbf{b}$. Photograph of PDC deposit and disturbance of small trees in the uppermost East Breach Creek drainage (see Fig. 1); trees are as much as $5 \mathrm{~cm}$ in diameter. Note the stratified nature of the deposit. Photographs by John Pallister, United States Geological Survey, January 2010.

lateral transport of ash was not likely the result of post-eruption aeolian reworking. Rills eroded in the deposit blanketing the hillslope showed that its upper surface was curviplanar. Deposit thickness was variable, from about 2-3 m, and suggestive of long-wavelength, low-amplitude dunes. The deposit is composed of curviplanar discontinuous beds of fine to coarse ash supporting scattered lapilli; bed thicknesses range from a few $\mathrm{mm}$ to about $20 \mathrm{~cm}$ (Fig 10c). Lapilli are composed dominantly of white pumice, but gray and red lithic fragments are also present.

\subsubsection{Interpretation and timing of deposits on the east side of Chaitén Volcano}

Collectively, the dune-like bedforms, stratified bedding, sediment composition and componentry, lack of charred vegetation, and downslope orientation of understory trees suggest that the deposits in the caldera moat and on the eastern flank are products of a series of dilute, low-temperature PDCs. We suggest that these PDCs were formed during small-volume collapses of the margins of eruption columns during one or more of the sus- 


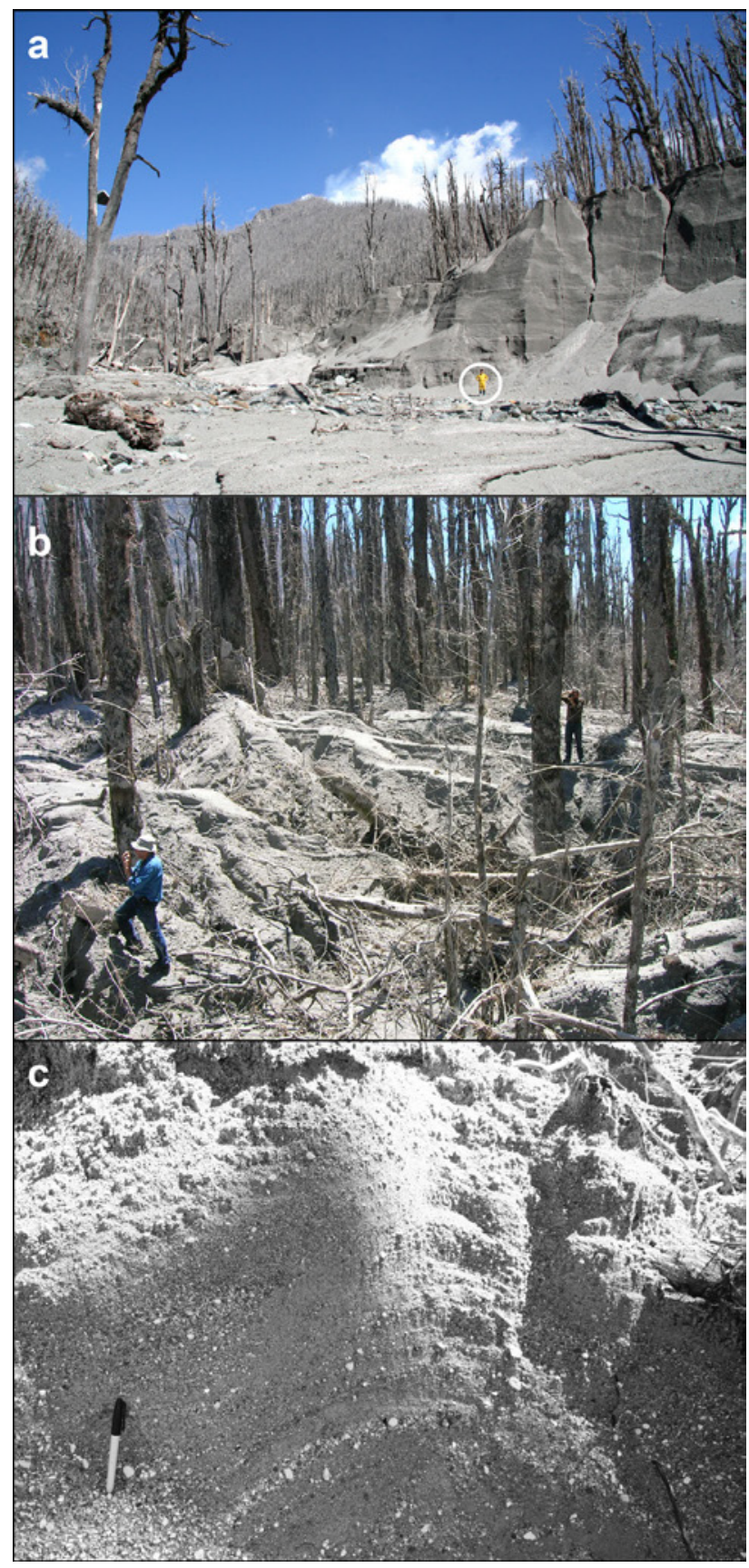

FIG. 10. Photographs of impacts and deposits of PDCs on east flank of Chaitén Volcano. a. Photograph looking up East Breach Creek from near confluence with East River. White fume just above photograph center is from Chaitén dome. Terrace deposits composed mainly of water-related flow sediment are well preserved on right of photograph. Note the boulder lodged in the large tree to the left, evidence that the valley was inundated to at least this level before deposits were incised. Note person (circled) for scale; $\mathbf{b}$. Photograph of upland PDC deposits in standing damaged forest about $3 \mathrm{~km}$ from east caldera rim. Note that small understory trees are broken and pointed in the downslope direction to the right. Note people for scale; c. Photograph showing PDC deposit detail along East Breach Creek about $3 \mathrm{~km}$ from east caldera rim. Note the stratified nature of the deposit, and the curviplanar nature of the bedding. Pen is about $14 \mathrm{~cm}$ long.

tained vertical eruptions during the first week of explosive activity. The PDCs deposited the largescale dunes in the eastern caldera moat, then moved down the East Breach Creek drainage where they deposited smaller-scale and finer-grained dunes. The proposed interpretation is consistent with observations of 'pyroclastic flows' moving down the East Breach Creek drainage on 8 May 2008 (SERNAGEOMIN, 2008b).

A patch of felled mature trees, many of which lie along contour, on the outer northeast flank of the volcano in the sub-basin immediately north of East Breach Creek (Fig. 4) suggests that an energetic PDC with a distinct lateral component also occurred on 
the northeast side of the volcano. We were unable to examine vegetation or deposits in that area. Owing to the strong similarity of forest disturbance here and on the north flank, we speculate that the PDC responsible for felling those trees probably occurred at the same time as the PDC on the north side, and it was likely generated by a similar mechanism.

On the basis of sedimentary textures and structures, such as pumice sand and gravel supported in a silty sand matrix, weak to sharp contacts between beds, and cross-cutting relationships among beds, we infer that the thick terraced fill at the confluence of East Breach Creek and East River mainly represents remobilized tephra from the steep valley slopes. In other basins, hillslope tephra was rapidly remobilized by rainfall and transported by hyperconcentrated flood flows and sediment-charged floods (Pierson et al., 2013). Extensive erosion of tephra fall from hillslopes in this east-side basin and sedimentary structures and textures in the terraced fill at the confluence indicate that similar processes transported and then deposited remobilized tephra on the relatively low gradient channel near the confluence.

\subsection{Chaitén River valley: south side of volcano}

Volcaniclastic deposition and forest disturbance in the Chaitén River valley, south of the volcano, differed considerably from those on the north and east sides. Multiple flowage deposits in that valley are locally many meters thick, and cover an extensive amount of the valley floor (Fig. 11). PDC deposits are composed predominantly of poorly sorted mixtures of coarse ash supporting polymictic lithic and minor pumice lapilli. In contrast, deposits related to flooding that occurred within days of the last large explosion on 8 May are finer grained, better stratified, and more pumiceous, because their sediment was derived from erosion of tephra (Pierson et al., 2013). The PDCs that affected the Chaitén River valley passed through a breach in the south caldera wall and along the tributary channel that we informally call Caldera Creek (Figs. 1, 4). At the time of our field investigation, the steepest proximal reach of Caldera Creek had been swept clean to bedrock, and local patches of uncharred, felled trees lined the channel tens of meters above the channel bed. Flows that swept down Caldera Creek deposited thick diamicts in the Chaitén River valley; they were associated with partial collapses of the newly formed lava dome (Pallister et al., 2013, this volume). Unlike tree disturbances on the north and east flanks, tree disturbance by PDCs and other flows in the Chaitén River valley was restricted to damage and burial along the channel margin and valley floodplain.

\subsubsection{Pyroclastic density current deposits in the Chaitén River valley}

Evidence for multiple flows of varying character varies with distance along the valley. Those flows include two principal PDCs, ash-cloud surge(s), and

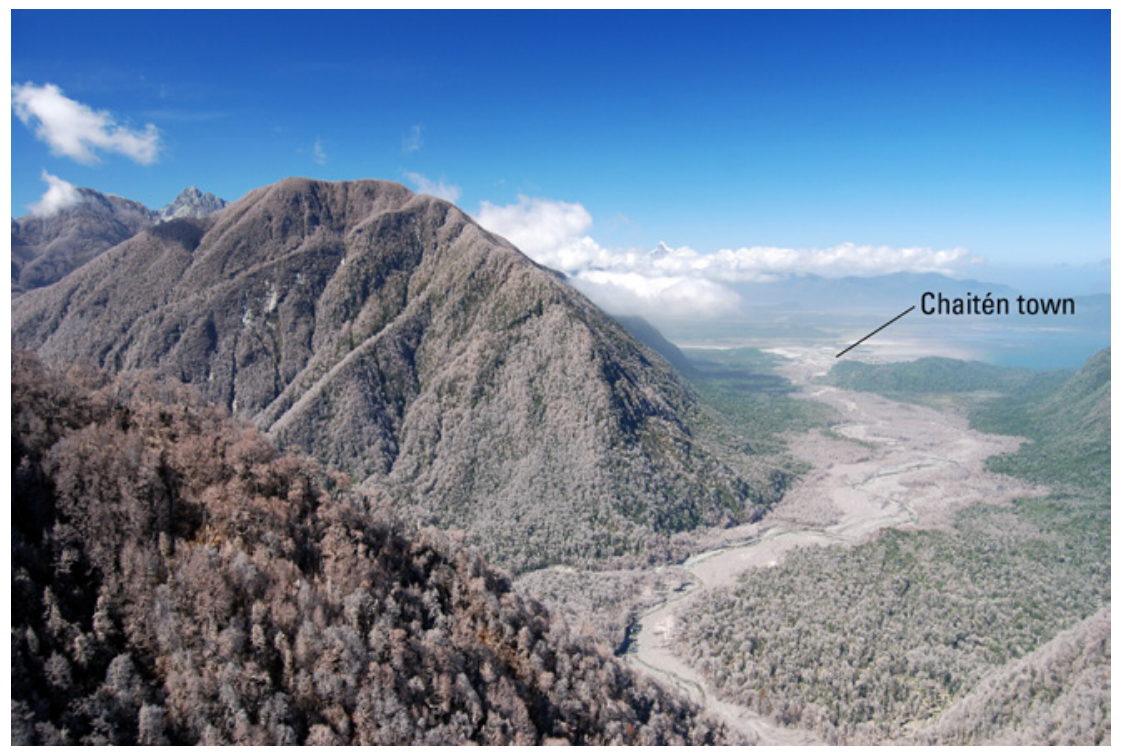

FIG. 11. Oblique aerial view of the Chaitén River valley looking downstream from near caldera rim. Note the extent of valley fill. Significant tree mortality on valley floor is the result of inundation by laharflood and PDC deposits and subsequent flooding during alluvial reworking of deposits. Chaitén town is $10 \mathrm{~km}$ from the center of the caldera. 
a complex lahar-flood. We broadly divide the area affected into proximal, medial, and distal reaches and discuss the character and sequencing of deposits in those reaches.

3.3.1.1. Proximal deposits. Clear evidence that at least two PDCs affected the Chaitén River valley is found where Caldera Creek merges with the valley floor. A sequence of six deposits is preserved there on the west side of the channel $3 \mathrm{~km}$ from the caldera rim (Fig. 12, location A; Fig. 13). 1. The lowermost deposit exposed (deposit 1) consists of at least $40 \mathrm{~cm}$ (base not exposed) of salt-and-pepper-colored, grain-supported, fines-depleted coarse to very coarse ash and fine lapilli. The deposit is massive to faintly stratified, and contains local lenses of fine ash 1-3 cm thick. It is composed of pumice and dark lithic ash, fine lapilli, and angular to subangular medium lapilli to about $1 \mathrm{~cm}$ diameter. Rare subangular to subrounded blocks of greenschist and black aphyric lithic fragments as large as $10 \mathrm{~cm}$ are entrained in the deposit. The deposit partly buries trees in growth position, and contains uncharred twigs, branches, and wood fragments. 2. Deposit 1 is sharply overlain by up to $2 \mathrm{~cm}$ of blue-gray, massive fine ash (deposit 2) having bits of twigs, leaves, and other organic debris on its surface. 3. Deposit 2 is

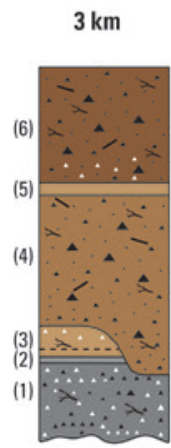

Location A
$3.4 \mathrm{~km}$

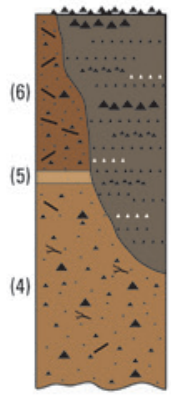

Location B
$3.6 \mathrm{~km}$

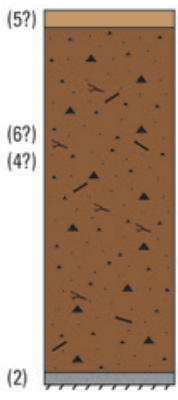

Location C

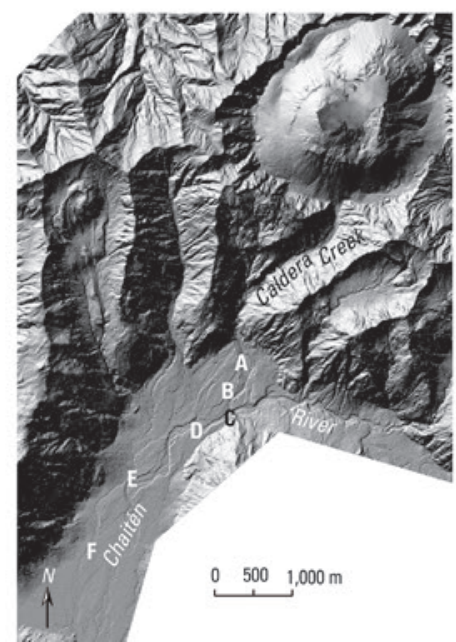

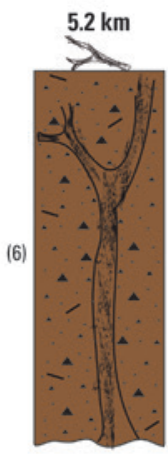

Location E

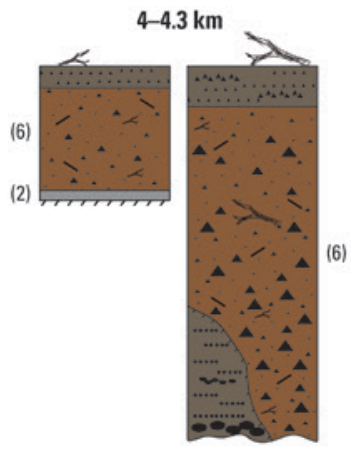

Location D

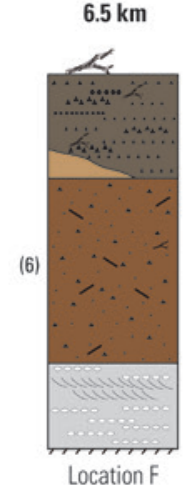

Explanation

$<$ uncharred wood fragment

$\checkmark$ charred wood fragment

II) cross bedding

subrounded pumice lapilli

- subrounded lithic gravel

$\triangle \quad$ angular/subangular pumice lapilli

A angular/subangular lithic lapilli and blocks

brown fine ash

gray fine ash

TrR pre-eruption surface

FIG. 12. Schematic stratigraphic sections of volcanic, volcaniclastic, and alluvial deposits in Chaitén River valley. The thin gray fine ash layer (deposit 2) is a tephra-fall deposit, the thick diamicts (deposits 4 and 6) are block-and-ash-flow deposits, and the brown fine ash layers (deposits 3 and 5) are inferred to be ash-cloud deposits related to the block-and-ash flows. The basal ashand-lapilli unit (deposit 1) may be related to a column-collapse PDC, but is of ambiguous origin. The stratified fill overlying deposit 6 is alluvially reworked sediment. The basal deposit at location $\mathrm{F}$ is a lahar-flood deposit related to rainfall erosion of tephra during the waning stages of the explosive phase of eruption (see Pierson et al., 2013). Section-location identifiers are tied to discussions in text. Inset digital elevation model shows locations of sections. Distances are relative to caldera rim. The sections are not drawn to scale. 

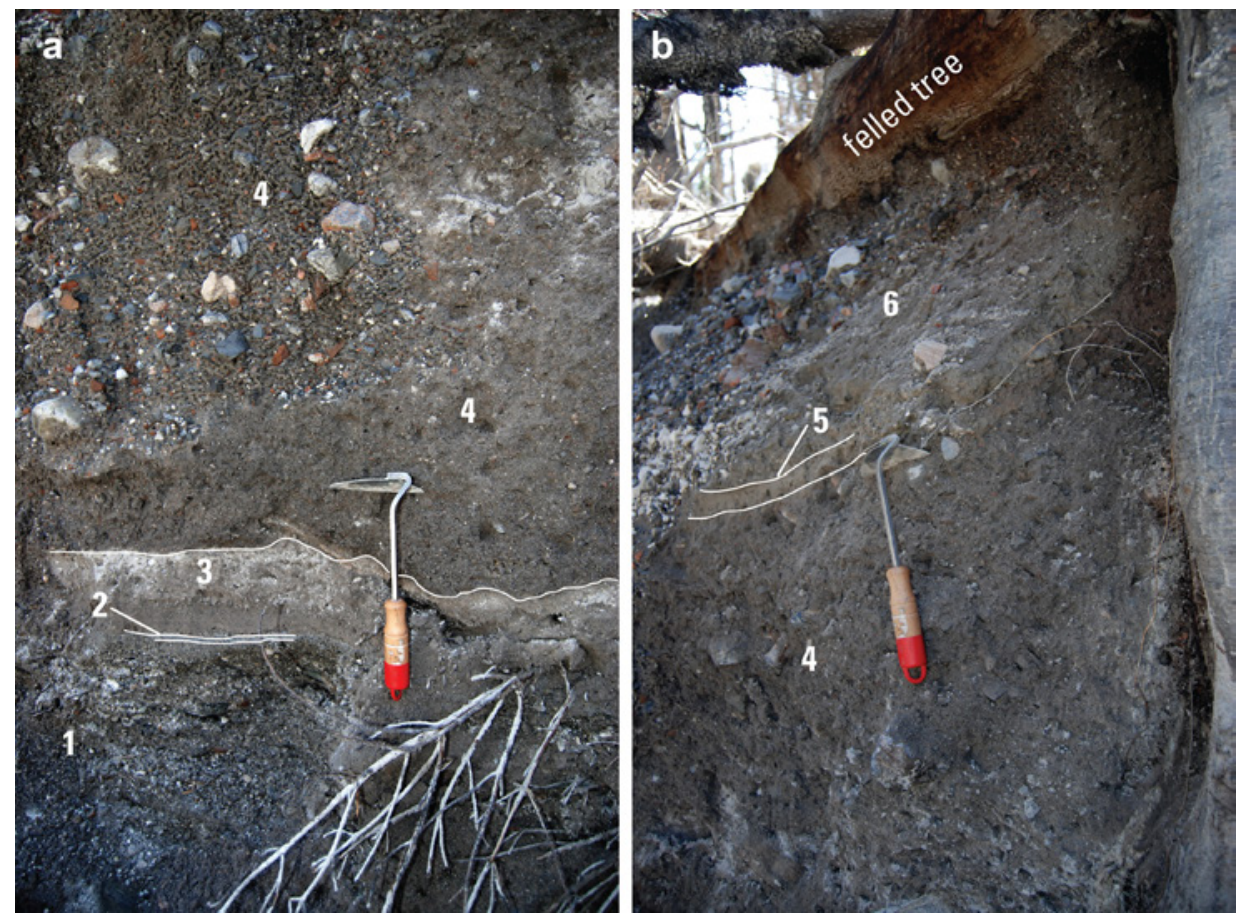

FIG. 13. Photographs of the sequence of deposits related to May 2008 explosive phase of eruption and subsequent dome collapses between June and November 2008 and in February 2009 preserved along Caldera Creek, a tributary leading from the caldera to Chaitén River. This sequence of deposits, and inferred deposit origins, is shown in schematic section A of figure 12. Scraper is $25 \mathrm{~cm}$ long. See text for description of deposits.

sharply overlain by up to $4 \mathrm{~cm}$ of brown, fine ash that grades into 10 to $15 \mathrm{~cm}$ of similar brown, massive, fine ash that contains pumice lapilli to $8 \mathrm{~mm}$, fragments of uncharred vegetation, and rare subangular lapilli of gray rhyolite to $1 \mathrm{~cm}$ diameter. Collectively, this fine ash is called deposit 3. Vegetation buried by deposits 1-3 is uncharred (Fig. 13). 4. Deposit 4 is a 1 to $2-m$ thick, poorly sorted, massive, brown polymictic diamict that sharply overlies and cuts through deposits 1-3. It contains angular to subangular medium to coarse lapilli and blocks of obsidian, oxidized (red) rhyolite, gray rhyolite, banded gray and black rhyolite, black rhyolite, and greenschist, commonly about 1 to 3 $\mathrm{cm}$ diameter and rarely as large as $10 \mathrm{~cm}$, supported in a moderately dense, poorly sorted ashy matrix (Figs. 12, 13). The deposit contains fragments of charred and uncharred wood, and locally it lightly chars the bark of buried trees. 5. Deposit 5, a massive, brown fine ash to $5 \mathrm{~cm}$ thick, sharply overlies deposit 4. Similar brown ash is found plastered on vertical surfaces along the valley wall. 6. A second poorly sorted, brown, massive, polymictic diamict, deposit 6 , is about $60 \mathrm{~cm}$ thick at this location, and it conformably overlies deposit 5 . The composition and size gradation of angular to subangular lithic lapilli and blocks in deposit 6 are similar to those of deposit 4, and they are also supported in a moderately dense, poorly sorted ashy matrix. Deposit 6 , however, contains local concentrations of pumice lapilli to $3 \mathrm{~cm}$ diameter. Like deposit 4, it contains (rare) fragments of charred wood, but it does not char the bark of buried trees at this location. Many trees encased in growth position by this sequence of deposits are removed or felled at the surface of deposit 6 (e.g., Fig. 13). Scattered pumice lapilli to a few $\mathrm{cm}$ diameter are found on the surface of deposit 6 , but it is not overlain by any of the tephra layers described by Alfano et al. (2011).

Tens of meters downstream of this exposure of multiple deposits, the two brown diamicts, deposits 4 and 6 , lie in conformable contact without, or with only a very thin layer of, the intervening brown ash (Fig. 14). Locally, deposit 6 pinches out where deposit 4 forms topographic swells or 


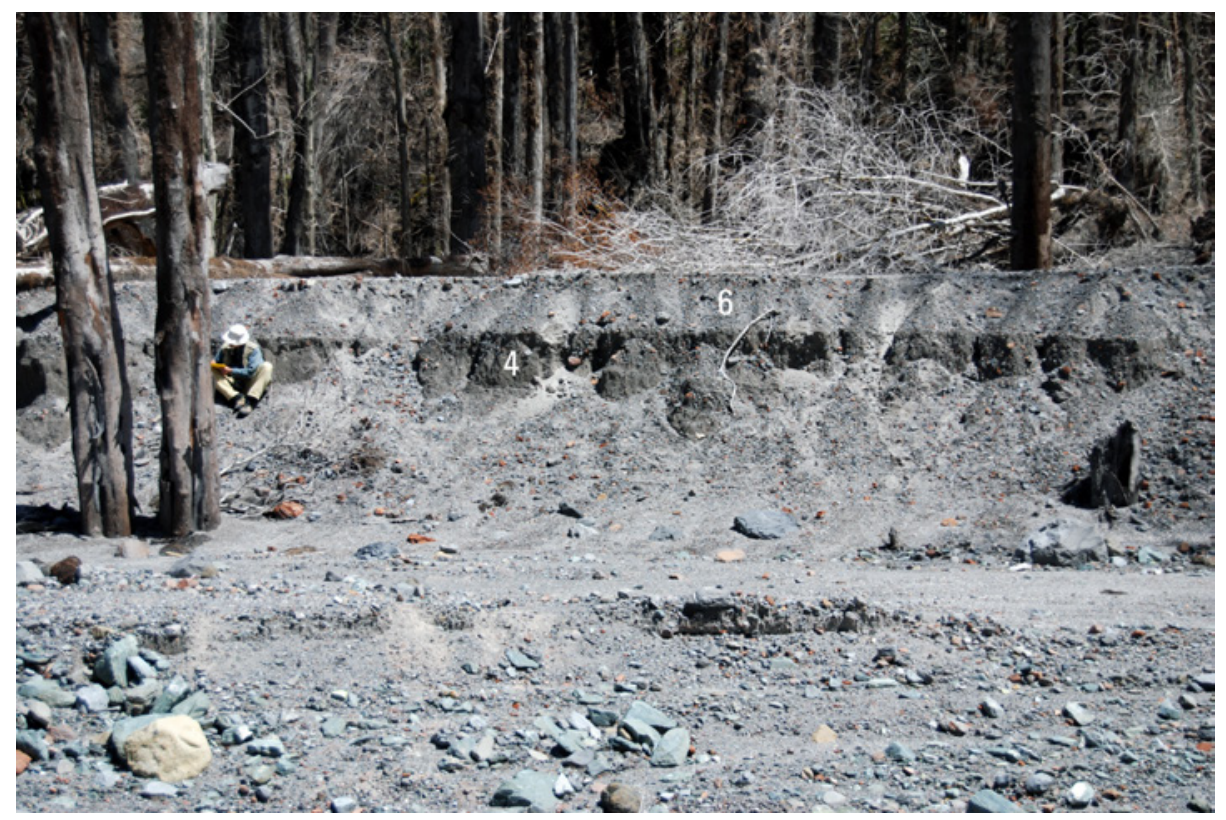

FIG. 14. Photograph of the two block-and-ash-flow deposits preserved along Caldera Creek upstream of the Chaitén River confluence. These two diamicts are deposits 4 and 6 shown in figure 12 (location A) and figure 13.

where overbank deposited lobes (1-1.5 m thick) terminate. In January 2010, the top of deposit 6 was $6 \mathrm{~m}$ above, and the top of deposit 4 was 5.5 $\mathrm{m}$ above, river level. The base of deposit 4 was obscured by alluvium, but limited exposure was found within $1.5 \mathrm{~m}$ of river level. Thus, at this location, deposit 4 was at least $4 \mathrm{~m}$ thick. Bark on the upstream-facing sides of trees buried by the diamict deposits is stripped to about $2 \mathrm{~m}$ above the maximum deposit level (about $8 \mathrm{~m}$ above the channel bed). In addition, moss on the downstream sides of trees is slightly charred.

In the same general area upstream of the confluence of Caldera Creek and Chaitén River, remnants of an inset alluvial fill, $6 \mathrm{~m}$ thick above the January 2010 river level and stratigraphically younger than deposit 6 , are preserved. That fill is composed predominantly of horizontally stratified, lithicand-pumice gravelly sand that contains angular to subangular pebbles and cobbles of rhyolite, older bedrock, and minor subrounded pumice.

Preservation of two diamicts persists with increasing distance along this reach. Along the west side of Caldera Creek near the confluence with Chaitén River, $3.4 \mathrm{~km}$ from the caldera rim, a sequence of four deposits is preserved (Fig. 12, location B). The lowermost unit,
4 meters thick above the January 2010 river level, is a grayish-brown, poorly sorted, polymictic diamict identical to deposit 4 farther upstream. Vegetation buried by the diamict is abraded to the deposit surface but uncharred. This diamict is overlain by another brown, poorly sorted, ashy, polymictic diamict that we infer is deposit 6. It is at least $3.5 \mathrm{~m}$ thick (the contact was not well exposed). Lithic clast compositions are similar to those in the underlying diamict, but are generally finer grained. Vegetation buried by deposit 6 is charred (Fig. 15a); wood to $4 \mathrm{~cm}$ diameter is charred completely, whereas larger diameter wood exhibits only surface char. Brown, massive fine ash as much as a few cm thick locally lies stratigraphically between the two diamicts. The two diamicts lie unconformably beneath an approximately 3 -m-thick alluvial fill composed of brownish-gray, poorly sorted but horizontally stratified, lithic-and-pumice very coarse sand that contains angular to subangular polymictic lithic gravel, and subordinate subangular to subrounded pumice gravel (Fig. 15b-e). The deposit surface supports a lag of lithic blocks (Fig. 15c), but is not covered by any tephra fall deposits. Vegetation buried by the deposit is uncharred, and trees buried by the underlying diamicts are commonly sheared off at its basal contact. 


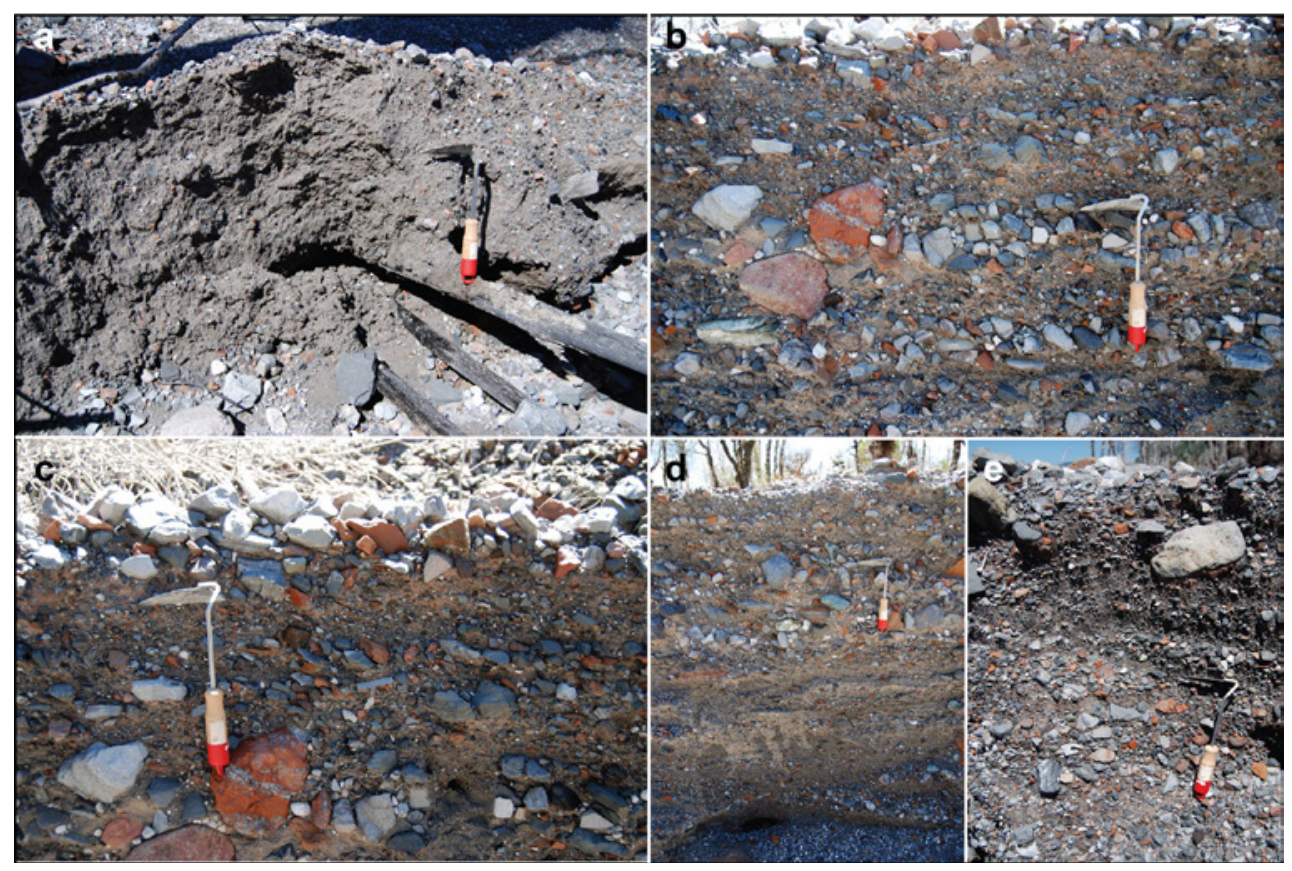

FIG. 15. Photographs of deposits near the confluence of Caldera Creek and Chaitén River (see Fig. 12, location B). a. Photograph of brown diamict (deposit 6) encasing charred vegetation; b-e. Photographs of stratified alluvial fill showing poor sorting, trains of coarse clasts, clast imbrication, and a coarse surface lag. This fill is inset against and unconformably overlies diamict deposits 4 and 6 (see Fig. 12, location B).

Preservation of two diamicts becomes scarce downstream of the Chaitén River confluence. Immediately downstream of the confluence on a 4-6 $\mathrm{m}$ high terrace on the east side of the valley, a $\sim 2 \mathrm{~m}$ thick massive, brown, polymictic diamict, containing predominantly 1-3 cm diameter lithic lapilli, subordinate $\mathrm{cm}$-sized pumice lapilli, bits of charred and uncharred vegetation, and having a moderately dense, vesicle-rich ashy matrix sharply overlies a loose, pumice-rich, fine-ash and fine-lapilli deposit that fully charred buried vegetation; the base of the ashy pumiceous deposit was not exposed. A few tens of meters upstream (Fig. 12, location C), nearly $6 \mathrm{~m}$ of massive, brown polymictic diamict that contains fragments of charred vegetation but left buried vegetation mostly uncharred sharply overlies 5 to $10 \mathrm{~cm}$ of gray fine ash that lies directly on the forest floor. The upper third of the diamict has a more compact and vesicle-rich matrix than does the lower bulk of the deposit. The diamict is sharply overlain by about $10 \mathrm{~cm}$ of brown, massive very fine ash; the pumiceous fine-ash and lapilli deposit was not observed in this section.
3.3.1.2. Medial deposits. Along the medial reach of the valley, 4-6 $\mathrm{km}$ from the caldera rim, only one diamict deposit is preserved, but it has locally variable character. Along the east side of the Chaitén River valley, 4.0-4.3 km downstream from the caldera rim (Fig. 12, location $\mathrm{D}$ ), about $1.5 \mathrm{~m}$ of brown, polymictic diamict overlies 7-13 cm of massive, gray, very fine ash on a terrace about 4-6 $\mathrm{m}$ above river level. The ashy matrix of the diamict contains fragments of charred wood, but buried vegetation is uncharred. The surface of the diamict has been fluvially reworked. Closer to the channel center, the diamict is coarser grained (mean lithic lapilli size of about $5 \mathrm{~cm}$ diameter); some angular lithic lapilli near the surface of the deposit are prismatically jointed. Adjacent to this outcrop, deeper incision even closer to the valley center exposes an 8-m-thick section of massive, brown, oligomictic diamict containing blocks of light gray rhyolite supported in a dense, poorly sorted ashy matrix (Fig. 12, location $\mathrm{D}$, right-hand section). Here, the texture of the diamict varies rapidly over a very short distance, from a relatively fine-grained facies containing $\mathrm{cm}$ sized lapilli to a very coarse-grained facies dominated 
by blocks tens of centimeters in diameter. Although the diamict contains fragments of charred wood, entrained tree trunks are uncharred. The base of the deposit was not fully exposed, although locally it lapped onto weathered alluvium. It is unclear which of the two diamicts exposed upstream this diamict represents, but we suspect it is probably the younger of the two, deposit 6.

At a distance of about $5 \mathrm{~km}$ from the caldera rim, massive, brown, poorly sorted, polymictic diamict thickly fills the channel (Fig. 12, location E; Fig. 16). Here, nearly $8 \mathrm{~m}$ of exposed diamict buries trees that are lightly to fully charred. Many of these trees are felled at the diamict surface, perhaps by wind or canopy burden after being weakened by charring (Swanson et al., 2013, this volume). A lag of pumice and lithic lapilli and blocks lies atop the diamict, and deposits of fluvial sand and gravel are inset. Locally, this diamict overlies gray fluvial sand that buries the lower parts of some of the trees encased within the diamict. Along the channel axis downstream of this exposure, and along the channel floodplain, meters-thick stratified, polymictic gravelly sand, similar to that observed along Caldera Creek and representing reworked PDC deposit, extends broadly across the valley floor.
3.3.1.3. Distal deposits. Thermal imagery (M. Bernstein, University at Buffalo, written communication, 2011; Major and Lara, 2013, this volume) shows hot deposit, which we infer to be deposit 6 , extending to a distance of $6 \mathrm{~km}$ from the caldera rim in February 2009. Between a distance of 5 to $6 \mathrm{~km}$ from the rim, charred trees in growth position have been exhumed from a relatively fine-grained (lapilli to $2 \mathrm{~cm}$ ), brown, poorly sorted, polymictic diamict (at least $40 \mathrm{~cm}$ thick; full thickness unknown). Slightly farther downstream (location F in figure 12) this diamict, deposit 6 , lies below a coarsegrained, stratified alluvial fill and locally beneath up to $30 \mathrm{~cm}$ of brown, massive fine ash, and above gray, horizontally stratified to cross-bedded pumice-bearing sand deposited by fluvial and hyperconcentrated flow associated with syneruptive flooding of the Chaitén River (Pierson et al., 2013).

\subsubsection{Timing of events and interpretations of deposits in Chaitén River valley}

The fill sequence in the Chaitén River valley is the product of events associated with the explosive phase of the 2008-2009 eruption, rainfall runoff, and collapses of the new lava dome subsequent to the explosive activity. The blue-gray ash overlying the

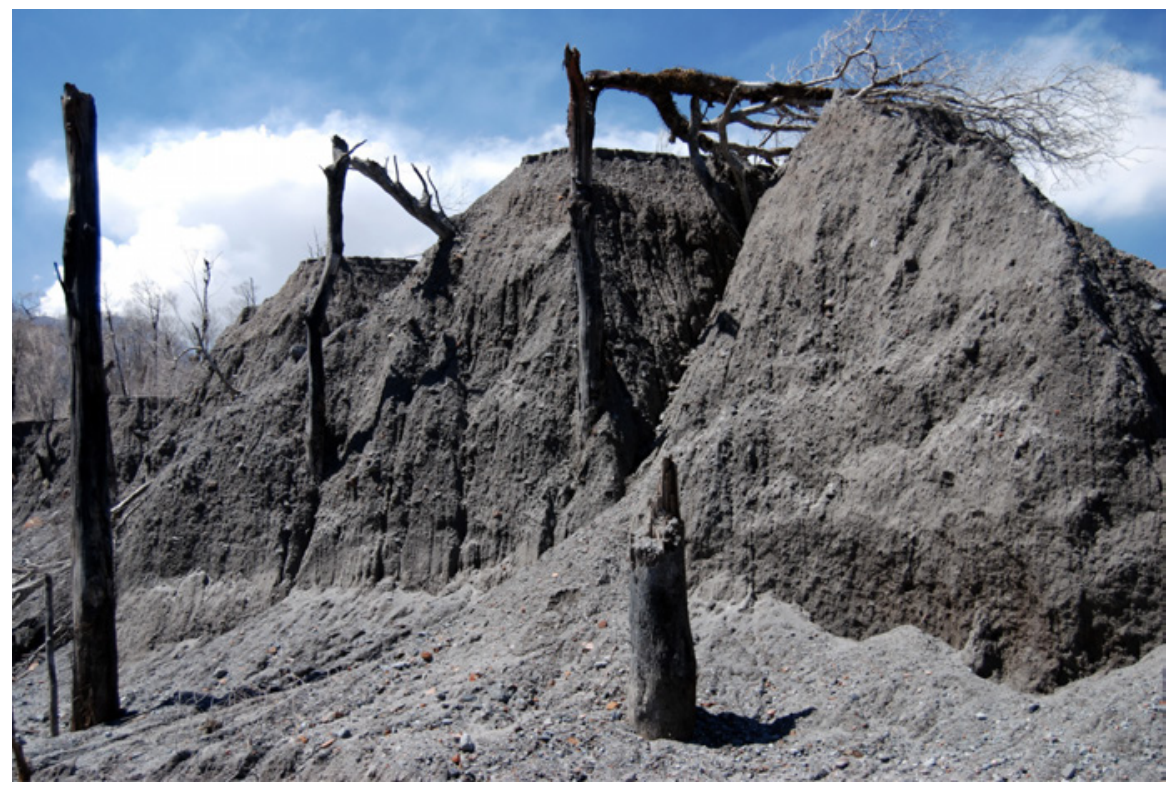

FIG. 16. Photograph of thick polymictic diamict (deposit 6) in the middle reach of Chaitén River valley, about $5.2 \mathrm{~km}$ from caldera rim (see Fig. 12, location E), related to dome-collapse PDC of February 2009. Exposed deposit about $8 \mathrm{~m}$ thick. Note how trees are broken and felled at the level of the deposit surface. Below this level, trees are partly to fully charred; above that level they are uncharred. 
salt-and-pepper-colored ash-and-lapilli unit along Caldera Creek above the Chaitén River confluence (Fig. 13, units 2 and 1) is a tephra fall related to the explosive phase of the eruption. Although its composition is not distinctive enough to assign it to a particular fall layer, we can broadly constrain its time of deposition. Locally on terrace surfaces near the valley walls, this blue-gray tephra overlies a buff to yellow-brown tephra fall that may be the $\alpha$-layer identified by Alfano et al. (2011) (Table 1). That tephra layer was inferred to have been deposited on 2 May. Because the $\alpha$-tephra layer does not overlie the salt-and-pepper-colored ash-and-lapilli unit (deposit 1; Figs. 12, 13), that unit was deposited late on or after 2 May. Although the blue-gray tephra is found at several locations along Chaitén River valley, it does not overlie flood deposits related to rainfall-runoff on 11-12 May (Pierson et al., 2013). The blue-gray tephra fall is thus bracketed between 2-11 May; Alfano et al. (2011) infer that most of the tephra to the southeast of Chaitén fell on 3-5 May (Table 1). The lithic-and-pumice composition of deposit 1 is similar to the composition of PDC deposits observed in the eastern moat and near the eastern rim of the caldera. That similarity in composition suggests an association with early explosive activity. Deposit 1 is not a tephra fall, because it is not found outside the channel. Its composition, the angularity of its clasts, its thickness, and its faintly laminated texture suggest that it could be the product of a PDC associated with partial collapse of one of the sustained vertical eruption columns. Here, however, deposition may have been affected by water. Aerial photographs show that one of the small intracaldera lakes that existed before the eruption continued to drain through the breach and along Caldera Creek during the explosive eruptive phase. It is therefore possible that a small-volume PDC, perhaps related to the same event that produced the salt-and-peppercolored beds in the eastern moat of the caldera, mixed with streamflow and formed a sediment-laden water flow that deposited this unit. The limited, local exposure of deposit 1 makes interpretation of its origin ambiguous, but it is clearly related to the early explosive phase of the eruption.

The predominantly lithic compositions, poorly sorted, unstratified textures, moderately dense matrices, thicknesses, and principally channel confinement of the brown diamicts indicate that they are the products of block-and-ash-flow (BAF) PDCs (e.g., Charbon- nier and Gertisser, 2011). Stratigraphy along Caldera Creek shows that there were at least two BAF PDCs that affected the Chaitén River valley. Eyewitness observations (Fig. 2) show that partial collapse of the lava dome on 19 February 2009 produced a PDC. Thermal imagery (M. Bernstein, University at Buffalo, written communication, 2011; Major and Lara, 2013, this volume) and a lack of any later PDCs exiting the caldera show that this collapse produced the younger of the two polymictic diamicts (Figs. 12, 13, deposit 6), which extended slightly more than $6 \mathrm{~km}$ from the caldera rim and is the thickest and most extensive diamict along the valley (as much as $8-10 \mathrm{~m}$ thick). The deposit covers slightly more than $1 \mathrm{~km}^{2}$ of valley floor. If we assume that it has an average thickness of 3-5 m, we estimate that it has a bulk volume of about $0.003-0.005 \mathrm{~km}^{3}$. Pallister $e t$ al. (2013, this volume) estimate that perhaps $10 \%$ (at least $0.05 \mathrm{~km}^{3}$ ) of the lava dome collapsed on 19 February 2009, whereas Bernstein et al. (2013, this volume) estimate about $0.02 \mathrm{~km}^{3}$ failed. Using either estimate, only a small fraction of the mass generated by that collapse exited the caldera.

On the basis of its similar texture and composition, the older of the two diamicts (Figs. 12, 13, deposit 4) was also emplaced by a PDC related to partial collapse of the new lava dome. Exact timing of that PDC is uncertain, but we can broadly bracket its occurrence through aerial imagery. Low-level oblique aerial photographs taken by SERNAGEOMIN geologists in early June 2008 show that although a flow of some type had moved down Caldera Creek, near-channel vegetation was still largely intact. In contrast, images from 2 November 2008 show that near-channel vegetation along the steepest proximal reach of Caldera Creek had been largely removed to a height of many meters above the channel floor, that the channel bed had been swept clean to bedrock, and that felled, downstream pointing trees lined the high-flow limit along the channel. These features show clearly that between early June 2008 and 2 November 2008, a substantial flow swept down Caldera Creek. The report from an observer flight on 24 July 2008 noted that a large collapse from the southern sector of the dome complex occurred between 22 and 23 July 2008 (SERNAGEOMIN, 2008e), but it made no specific mention of new valley deposits. Because deposit 4 is the only thick, massive deposit that lies above the blue-gray tephra fall (deposit 2) associated with the explosive phase of eruption and beneath the Febru- 
ary 2009 dome-collapse PDC deposit (deposit 6), and because deposit 4 has a texture and composition that are virtually identical to those of deposit 6 , we infer that the event that produced deposit 4 reamed Caldera Creek channel and that it was also a BAF related to partial dome collapse. Perhaps the collapse on 22 or 23 July 2008 is the source event.

Deposits 3 and 5 along Caldera Creek (massive fine ash; Figs. 12, 13) show that relatively cool ashcloud phases (vegetation not charred in these deposits) preceded, and possibly followed, each BAF flow. These low-concentration flow phases are commonly associated with dome collapse and form when fine ash rapidly generates and segregates from the underlying high-concentration flow (Branney and Kokelaar, 2002). The pumiceous ash-and-lapilli deposit that contains charred wood fragments, preserved near the confluence of Caldera Creek and Chaitén River, shows that a hot surge preceded one of the block-and-ash flows. Its pumice content suggests that it might correlate with deposit 3 , but deposit 3 does not contain charred wood fragments. Because the February 2009 dome collapse produced the largest BAF, and because its deposit shows the most evidence of heat, it is possible that the hot surge was associated with that event. If so, then a subsequent ash cloud locally deposited fine ash atop deposit 6 (e.g., Fig. 12, location C).

The BAFs in the Chaitén River valley likely mixed with streamflow and may have formed local lahar slurries. Mixing of those PDCs with streamflow may explain some of the variation of matrix density and the vesicle-rich facies observed in the diamicts along the valley. However, neither one mixed sufficiently with water to trigger lahars that flowed all the way down valley.

The PDC deposits were extensively eroded and reworked. Stratigraphic relations, deposit architecture, and sediment composition suggest that the thick polymictic, stratified fills found along Caldera Creek and farther downstream along Chaitén River are largely the consequence of sediment reworking following emplacement of the February 2009 PDC. Figure 17 summarizes our inferences of the sequence and timing of events that affected Chaitén River valley.

\section{Pyroclastic density currents: dynamics and tem- peratures inferred from vegetation disturbance}

Physical characteristics of tree disturbance, thermal impacts on vegetation, and deposit thick- ness and extent can be used to estimate the dynamic pressure, speed, average sediment concentration, and temperature of a pyroclastic density current (e.g., Clarke and Voight, 2000; Moore and Sisson, 1981; Winner and Casadevall, 1981; Hudspith et al., 2010). Estimates of those properties are subject, however, to many simplifying assumptions. The following analysis of PDC dynamics applies only to the north-side event, because our most constrained data are from that event. It assumes that tree felling was accomplished chiefly by the pressure exerted by passage of a PDC, but we acknowledge that transport of felled trees and large pieces of wood subjected the forest to impact forces, and that a domino effect likely contributed to felling (Swanson et al., 2013, this volume). We also assume that toppled trees were mostly delimbed by the PDC before felling (although collisions among falling trees likely contributed to limb loss), that delimbed trunks can be approximated as cylinders subjected to fluid drag, and that the flow was vertically uniform (even though it was at least longitudinally stratified). Clarke and Voight (2000) show that results obtained from a simplified analysis assuming vertically uniform flow are similar to those obtained from more sophisticated analyses based on vertically nonuniform flow.

\subsection{Pyroclastic density current dynamics}

As shown by Clarke and Voight (2000), the minimum aerodynamic pressure (in $\mathrm{kPa}$ ) applied to an isolated cylindrical pole by a vertically uniform current is related to the bending moment at failure $(M)$, the height of the pole above the plane of failure $(h)$, the radius of the pole $(r)$, and the coefficient of aerodynamic drag $\left(C_{D}\right)$ by

$$
P_{d y n}=\frac{M}{r h^{2} C_{D}}
$$

On the north side of Chaitén Volcano, most felled trees were uprooted rather than broken, especially Coihue and Tineo (Figs. 5, 6). Therefore, a critical uprooting moment rather than a breaking moment is needed to estimate the dynamic pressure. Field experiments suggest that uprooting moments (in $\mathrm{N}-\mathrm{m}$ ) for a number of tree species having various rooting depths and growing on a variety of soils range broadly from 100-200 times the trunk weight 
a

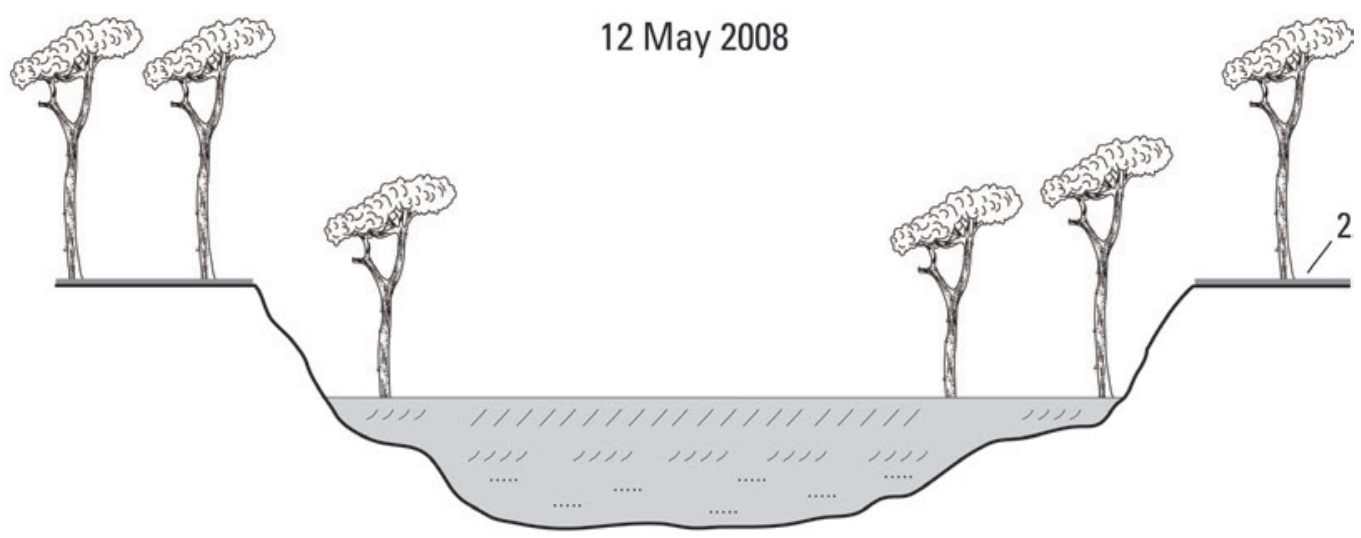

b

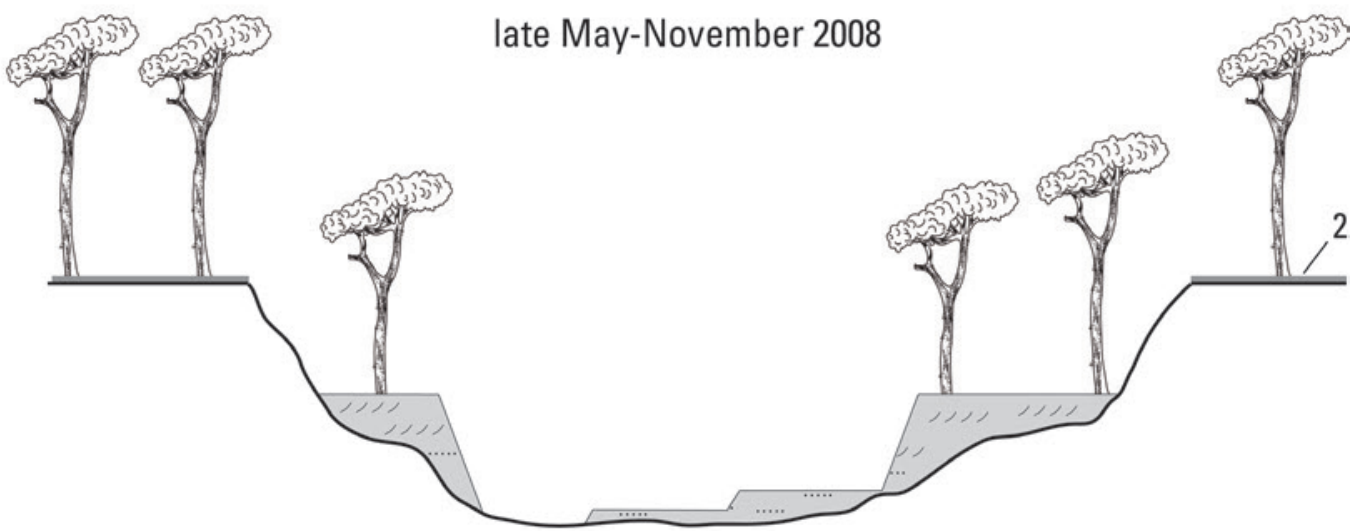

C

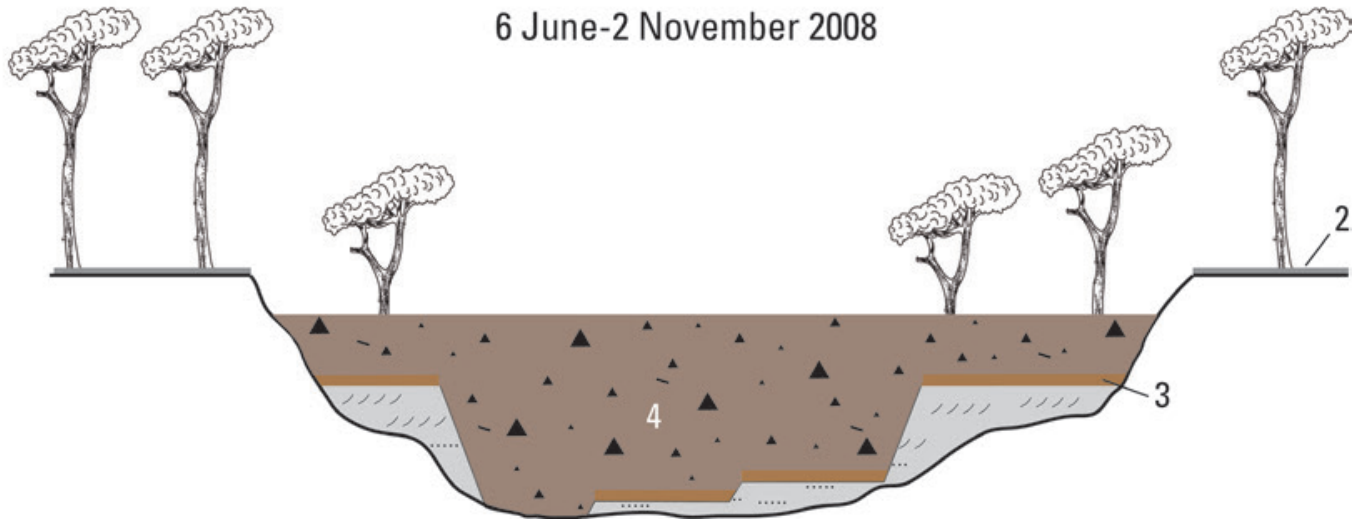

d

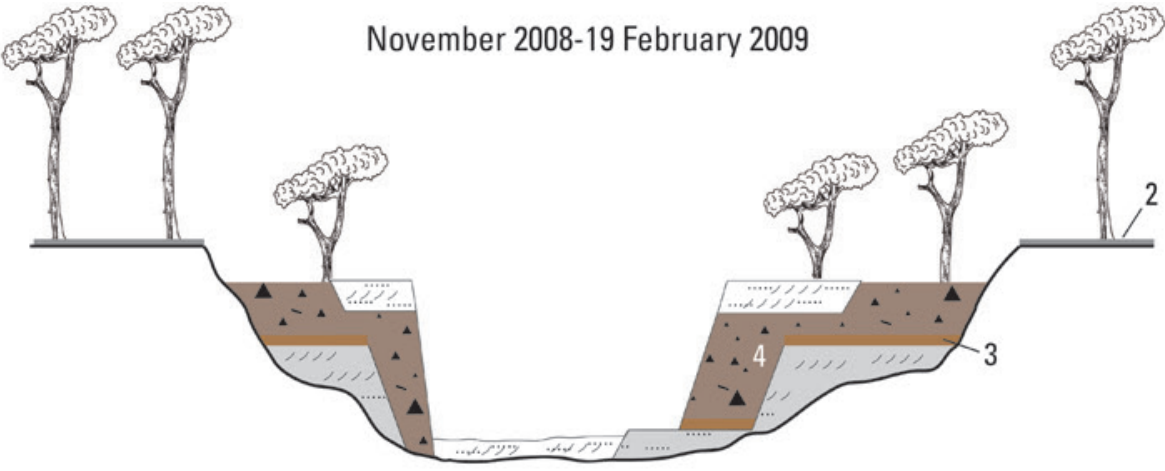

e
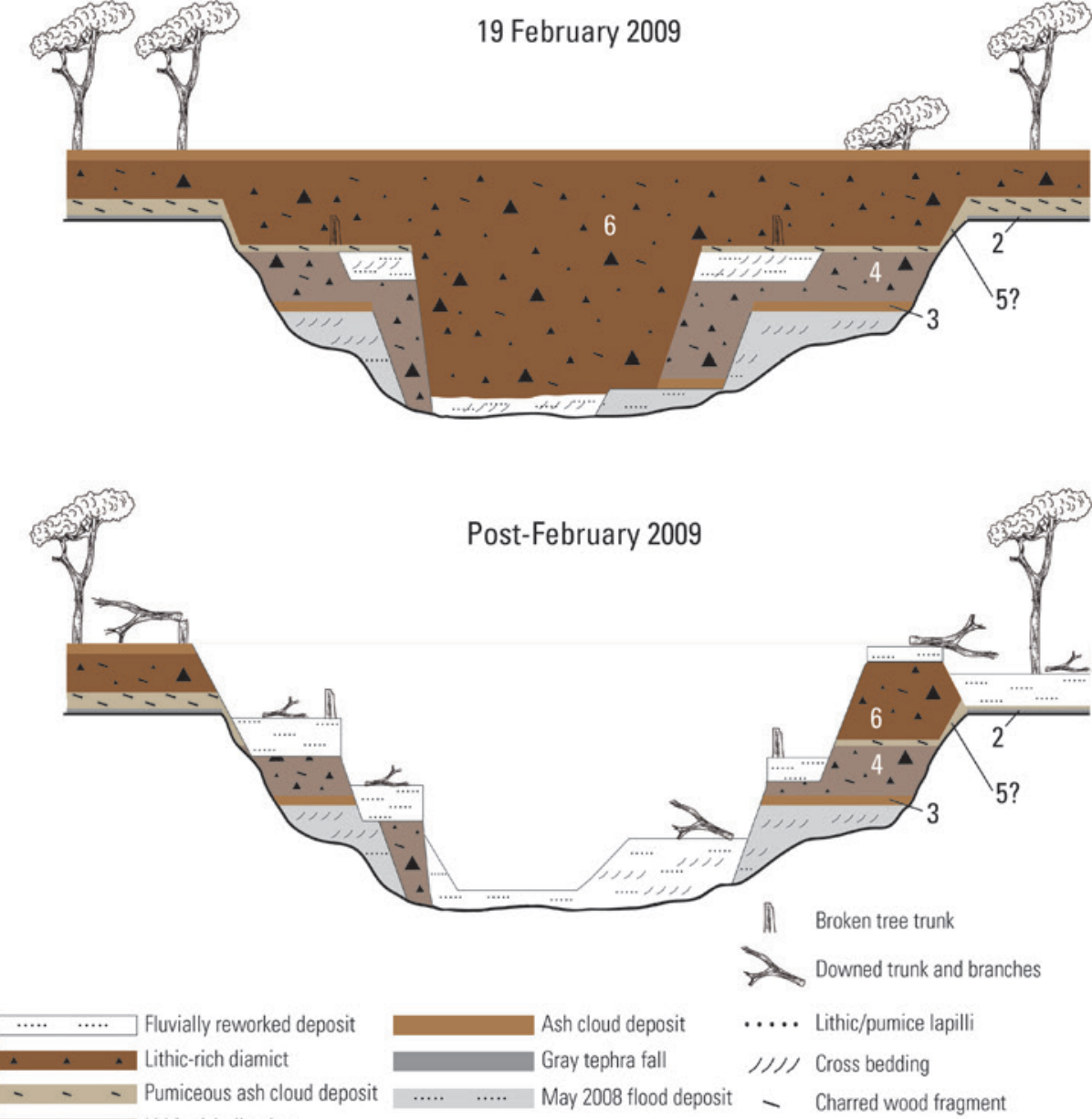

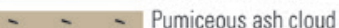
Gray tephra fall

נノ) Cross bedding

- Angular/subangular lithic blocks and lapilli

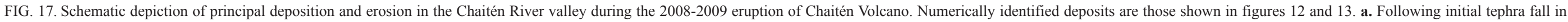

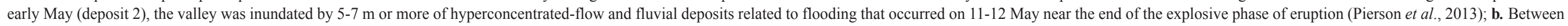

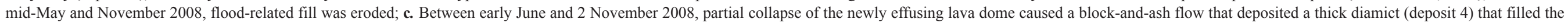

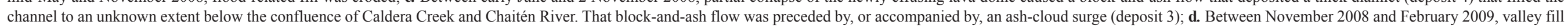

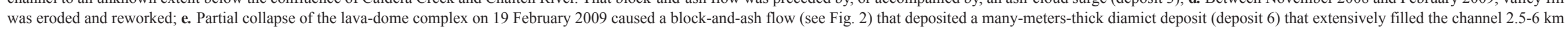

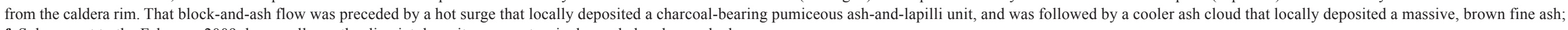
f. Subsequent to the February 2009 dome collapse the diamict deposits were extensively eroded and reworked. 
(in $\mathrm{kg}$ ) of the tree (Élie and Ruel, 2005; Nicoll et al., 2006; Byrne and Mitchell, 2007). Although the species examined in these field tests are not the species found in northern Patagonia, we use these broad results to constrain possible uprooting moments of trees at Chaitén Volcano. To estimate trunk weights of felled trees, we need an estimate of tree volumes and densities. Measurements of several felled trees reveal a mean trunk length of $27 \mathrm{~m}$ and a mean diameter at breast height of $0.9 \mathrm{~m}$. We assume trunks taper linearly along their lengths, and that the mean diameter of a trunk top is $0.3 \mathrm{~m}$. From these measurements, we model felled trees as truncated cones, which yields an average felled-tree volume of about $8 \mathrm{~m}^{3}$. Density of green wood varies considerably by species. At Chaitén, the predominant tree species (Ulmo, Coihue, Tineo) have green densities of about $600-650 \mathrm{kgm}^{-3}$ (www. thewoodexplorer.com). Under our assumptions, we estimate that felled trees at Chaitén have a typical trunk weight of 5,000-6,000 kg, and thus critical uprooting moments of about $0.5-1 \mathrm{MN}-\mathrm{m}$. If we further assume that the felled trees have an average radius of $0.3 \mathrm{~m}$ and that $C_{D} \sim 1.1$ (Clarke and Voight, 2000), equation (1) shows that the minimum dynamic pressure of the north-side PDC ranged from about 2-4 kPa. If trees retained significant limb structure at the time they were felled, the drag coefficient would have be greater, and dynamic pressure needed to cause uprooting failure could have been substantially lower.

Measurements of deposit thickness and observations of tree abrasion can be used to estimate the average concentration of the PDC. Many felled trees retained their bark, although lianas were abraded from vent-facing sides of trees. Felled trees having vent-facing bark removed showed little abrasion of the underlying wood. Within about $1.3 \mathrm{~km}$ of the caldera rim, limbs were completely removed and swept farther downslope, whereas at greater distance shattered limbs lie about felled trees, suggesting that they were removed as trees fell. Beneath felled trees, the PDC deposit was thin to absent, whereas it lapped against vent-facing rootwads. Standing snags had bark removed on vent-facing sides and the underlying wood was uniformly, but not severely, abraded along snag length (Fig. 6). These observations suggest that the PDC was dilute and not strongly stratified vertically, likely of short duration (perhaps a few minutes), and that felled trees were uprooted upon or shortly after arrival of the PDC. Abrasion limits and removal of tree limbs along the lengths of the trunks suggest that the body of the PDC was at least as thick as the felled trees were tall ( $>15-30 \mathrm{~m})$, excluding the elutriated ash cloud that billowed above. From Clarke and Voight (2000), the maximum average concentration of a PDC, which represents the maximum average volumetric proportion of solids per meter of current width passing a failed object's position, can be estimated as

$C_{\text {avg }}=\frac{E}{100 h_{c}} \frac{\left(t_{0}-t_{f}\right)}{\ln t_{0}-\ln t_{f}}$

where $t_{0}$ is the thickness of the deposit (in $\mathrm{cm}$ ) at distance $R_{0}$, typically chosen as the distal limit of the deposit, $t_{f}$ is the thickness of the deposit (in $\mathrm{cm}$ ) at the site of tree failure, $E$ is the volumetric void ratio of the deposit, and $h_{c}$ is the depth of flow (in $\mathrm{m}$ ). This expression is based on the assumption that sediment was deposited instantaneously downstream of an arbitrary reference point, that all suspended sediment in the current is captured in the deposit, and that deposit thickness decreases exponentially with distance downstream from an arbitrary reference point. At Chaitén, our data are insufficient to test whether the deposit thins exponentially with distance. For purposes of calculation, we assume that the distal-limit thickness $\left(t_{0}\right)$ of the PDC deposit ranges from $0.1-1 \mathrm{~cm}$ (limited measurements by Swanson et al. (2013, this volume) show distal thicknesses as great as $2-3 \mathrm{~cm}), t_{f}=30 \mathrm{~cm}$, $h_{c}=15-50 \mathrm{~m}$, and that the volumetric void ratio has a nominal value $E=0.7$. Under these assumptions, and using (2), we estimate that the maximum average concentration of the PDC ranged from about $5 \times 10^{-4}$ to $5 \times 10^{-3}$, with a modal value of about $1 \times 10^{-3}$.

The maximum average bulk density, $\rho_{\text {avg }}$, corresponding to maximum average flow concentration is given by (Clarke and Voight, 2000):

$$
P_{a v g}=C_{a v g} P_{s}+\left(1-C_{a v g}\right) P_{v a p}
$$

where $\rho_{s}$ is the average density of the suspended solid particles and $\rho_{\text {vap }}$ is the average density of the suspending fluid. Because the lower facies of the PDC deposit is about $50 \%$ pumice and subpumice, $40 \%$ lithic, and $10 \%$ obsidian, and the upper facies is about $30 \%$ pumice and subpumice, $60 \%$ lithic, and $10 \%$ 
obsidian, we assume an average suspended-particle density of about $1,700 \mathrm{kgm}^{-3}$. The composition of the gaseous suspending fluid was likely dominated by air and water vapor, having densities that are temperature dependent. For reasons discussed below, we assume that the temperature of the $\mathrm{PDC}$ was probably in the range of $50^{\circ} \mathrm{C}$ to $200^{\circ} \mathrm{C}$. At $50^{\circ} \mathrm{C}$, water vapor has a density of $0.671 \mathrm{kgm}^{-3}$, and at $200^{\circ} \mathrm{C}$ it has a density of $0.458 \mathrm{kgm}^{-3}$. Using the estimated modal value of the average current concentration and the estimated average particle and fluid densities, equation (3) shows that the PDC possibly had an average bulk density of 2-3 $\mathrm{kgm}^{-3}$. By comparison, a fluid debris flow commonly has an average bulk density of 2,000 kgm ${ }^{-3}$ (Costa, 1984).

The dynamic pressure of the PDC is related to its velocity and average bulk density by

$$
P_{d y n}=\frac{1}{2} P_{a v g} V^{2}
$$

Inverting (4) and using our estimates of minimum dynamic pressure and maximum average bulk density, we can roughly estimate that the PDC had a minimum, near-ground velocity of $30-40 \mathrm{~ms}^{-1}$. Our estimated values for minimum dynamic pressure and maximum average current concentration at Chaitén Volcano are consistent with those estimated for pyroclastic density currents from eruptions of Unzen, Mount St. Helens, Lamington, Merapi, and Soufrière Hills Volcano (Valentine, 1998; Clarke and Voight, 2000; Loughlin et al., 2002; Sparks et al., 2002; Baxter et al., 2005; Scott et al., 2008). Velocity estimates are similar to those observed or estimated for PDCs at Unzen, Lamington, Merapi, and Soufrière Hills Volcano (Clarke and Voight, 2000; Kelfoun et al., 2000; Sparks et al., 2002), but they are much less than those estimated for PDCs related to the lateral blast at Mount St. Helens in 1980 (Clarke and Voight, 2000) or associated with the 1902 eruption of Mont Pelée (Tanguy, 1994).

Although field evidence suggests that the north (and northeast) side PDC was energetic and probably had an initially lateral component to its trajectory, these analyses suggest that the lateral component was not especially strong. The estimated minimum dynamic pressure and velocity are similar to those of PDCs that did not have initial lateral trajectories (e.g., Clarke and Voight, 2000).

\subsection{Pyroclastic density current temperatures}

At other volcanoes, some pyroclastic density currents were capable of charring standing and entrained vegetation during flow passage (e.g., Taylor, 1958; Moore and Sisson, 1981; Sigurdsson et al., 1984; Voight and Davis, 2000), melting telemetry cables (Fujii and Nakada, 1999), and destructively distilling vegetation into tar (e.g., Sparks et al., 2002; Scott et al., 2008) as far as several $\mathrm{km}$ from source. In contrast, trees damaged by the north-side PDC at Chaitén are not charred (except locally at the rim), and buried organics are charred only locally where the PDC deposit was many tens of $\mathrm{cm}$ thick. At the margin of the PDC, there is a thin zone in which tree foliage appears to have been killed by heat (Swanson et al., 2013, this volume; Fig. 4). A similar singe zone was observed at the margin of the area affected by the directed blast of the 1980 eruption of Mount St. Helens (Winner and Casadevall, 1981) and at the margin of a zone of trees damaged by PDCs at Merapi (Kelfoun et al., 2000). Experiments by Winner and Casadevall (1981) suggest that temperatures required to singe tree foliage at Mount St. Helens ranged from $50^{\circ} \mathrm{C}$ to $200^{\circ} \mathrm{C}$. Heat damage to $\mathrm{PVC}$ roofing material within a singe zone at Merapi suggests a singe-zone temperature of about $100^{\circ} \mathrm{C}$ (Voight and Davis, 2000). Analysis of wood combustion indicates that dry timber from several tree species begins to char at $450^{\circ} \mathrm{C}$ after one minute (Grønli and Melaaen, 2000; Bryden et al., 2002), and green timber chars only after several minutes of exposure to high heat $\left(>200^{\circ} \mathrm{C}\right)$. Dry wood chars slowly (3-5 $\mathrm{cm} \mathrm{hr}^{-1}$ ) with long exposure to temperatures as low as $120^{\circ}-150^{\circ} \mathrm{C}$ (www.tcforensic.com.au/ docs/article10.html), whereas wet logs thinly buried by PDC deposits can be heated to $200^{\circ} \mathrm{C}$ yet remain uncharred (Hudspith et al., 2010). Experiments show that Douglass fir wood at Mount St. Helens was heavily charred at $350^{\circ} \mathrm{C}$ after two minutes, but charred only lightly at $300^{\circ} \mathrm{C}$ (Moore and Sisson, 1981). The majority of wood within the Mount St. Helens blast deposit, however, was uncharred, and direct measurements of deposit temperature were less than $200^{\circ} \mathrm{C}$ (Hoblitt, 1996). From these characteristics of wood combustion and limited thermal data, and from our observations of minimal thermal impacts on trees and buried organics at Chaitén, we infer that the north-side PDC was of short duration, that its thin (a few tens of $\mathrm{cm}$ ) deposit cooled quickly, 
and that its temperature was moderate relative to the other PDC examples noted above, perhaps in the range of $50^{\circ}-200^{\circ} \mathrm{C}$.

Forest disturbance in the Chaitén River valley shows more evidence of heat than do disturbances on other flanks of the volcano. Although PDCs in the Chaitén River valley did not char vegetation during passage, some large trees encased in their deposits are fully charred. Temperatures of the block-and-ash flows in the Chaitén River valley were perhaps as high as $300^{\circ} \mathrm{C}$ locally.

\section{Discussion}

The explosive phase of the eruption of Chaitén Volcano in May 2008, and partial collapses of its lava dome between June and November 2008 and in February 2009, produced several relatively lowto moderate-temperature (probably $<200^{\circ}-300^{\circ} \mathrm{C}$ ) pyroclastic density currents that affected the north, northeast, east, and south sides of the volcano. Mobile currents were focused as they surmounted low divides in the caldera rim and followed major drainages. Patterns of felled trees show that PDCs to the north and northeast were guided largely by topography, but that currents were sufficiently energetic and mobile to locally flow along contour nearly perpendicular to downslope direction and over minor topographic barriers. In contrast, PDCs to the south were tightly funneled along a tributary that breaches the caldera rim and then spread along the middle to lower reaches of the Chaitén River valley floor.

To the north, an energetic event produced a relatively low- to moderate-temperature (probably $<200^{\circ} \mathrm{C}$ ), low-concentration PDC that overtopped the 200-m-tall caldera wall and felled trees over an area of about $4 \mathrm{~km}^{2}$ on the volcano's outer flank. It left a bipartite deposit a few tens of centimeters thick. The deposit is composed of a lower layer of friable, poorly sorted, grain-supported, strongly fines-depleted pumice-and-lithic very coarse ash and fine lapilli, locally mixed with substrate soil and vegetation near its basal contact. That lower layer transitions abruptly into an upper layer of poorly sorted, fines-enriched, pumice-and-lithic ash. The characteristics of this bipartite deposit are very similar to those described for deposits of directed blasts from explosive andesitic and dacitic eruptions (Belousov et al., 2007). Evidence from physical damage to trees, which shows that flow depth (>15-30 m) greatly exceeded deposit thickness and that sediment concentration was relatively uniform throughout the flow column, indicates the PDC was significantly inflated and not strongly vertically stratified. The bipartite nature of the deposit, however, indicates that the flow was at least longitudinally stratified. On the basis of stratigraphic relations with overlying tephra falls and eyewitness observations, we conclude that that event possibly occurred as early as 2 May during the early explosive phase of eruption, but it may have occurred several days later, perhaps during the climactic explosion on 6 May.

The PDC that affected the northeast side of the volcano was likewise energetic and mobile. It felled an approximately $2 \mathrm{~km}^{2}$ swath of forest and left several felled trees oriented along topographic contour. However, other than its impact on vegetation, we know little about that PDC owing to our inability to access its disturbance zone and deposit. Owing to the similarities in the nature and restricted focus of forest disturbance caused by the north- and northeast-side PDCs, and to evidence of substantial mobility, we speculate that the two events had a similar nature and eruptive origin, and that they probably occurred at about the same time.

Despite producing a deposit having 'blast-like' characteristics, the explosive eruption of Chaitén lacked a typical blast-generating mechanism. Directed blasts are typically associated with rapid removal of part of a volcano, either by sector failure or dome collapse, and sudden decompression of a shallow magma body of andesitic or dacitic composition and its surrounding geothermal fluids (e.g., Hoblitt, 2000; Sparks et al., 2002; Alvarado et al., 2006; Belousov et al., 2007). That type of sudden unloading triggers rapid, laterally-directed decompression which not only causes the initial high-energy burst to initiate the blast, but also controls the lateral direction of the blast. At Chaitén, however, there was neither sector failure nor dome collapse capable of rapidly decompressing the magma body and controlling the direction of a blast. Indeed, early photographs of the eruption show two open vents on the side of the old lava dome with no evidence of mass failure in the caldera (Fig. 18; SERNAGEOMIN, 2008a). Vertically directed explosions can also produce blast-like events as the eruption cloud rapidly collapses around the vent. The most recent example occurred in 1991 at Mount Pinatubo (Hoblitt et al., 1996). But this 
mechanism typically produces a radial distribution of blast effects, which was not present at Chaitén. Instead, we hypothesize that rapid decompression associated with dual-vent-opening above a very shallowly emplaced magma (Alfano et al., 2012) directed energetic explosions of gas, fragmented magma, and old dome debris which were focused to the north and northeast.

Directionally focused explosions are known to occur with vent opening. The best documented example occurred during the 1902 eruption of Mont Pelée, Martinique (Tanguy, 1994). Like Chaitén, this occurred as a dormant, dome-producing volcano reawakened. As new magma invades an old dome, gases initially escape through the most propitious fissures. These escape routes are apt to be oriented at some angle to the vertical, and thus explosions can be directionally focused. However, even if a vent is oriented vertically, vent asymmetry can cause tilting and directional focusing of eruption columns. Numerical simulations show that when vent pressure is high and the diameter of the exit through which magma erupts is small relative to that of the volcanic conduit, asymmetry in the shape of the vent exit can induce strong tilting and directional focusing of the eruption column (Lagmay et al., 1999; Sim and Odgen, 2012). As vent pressure declines and the ratio of the diameter of the vent exit to volcanic conduit increases, eruption columns are thrust more vertically. Opening of pathways through the old lava dome at Chaitén produced narrow, asymmetrically shaped vents (Fig. 18; SERNAGEOMIN, 2008a) which gradually widened as the eruption progressed. We posit that the geometries of those vents were likely the main controls that focused the north and northeast-side PDCs during the early explosive phase of the eruption and led to the blast-like nature of those flows and their consequent deposits.

Similarly dilute, but less energetic PDCs affected the east flank of Chaitén along East Breach Creek drainage. Lack of significant tree abrasion much beyond the caldera rim, meters-high sediment veneers on trees, felling and shearing of small understory vegetation but not larger trees, and curviplanar bedforms all indicate that the PDCs that affected the east flank were relatively dilute and less energetic than those to the north and northeast. Lack of char on standing trees and buried vegetation shows that

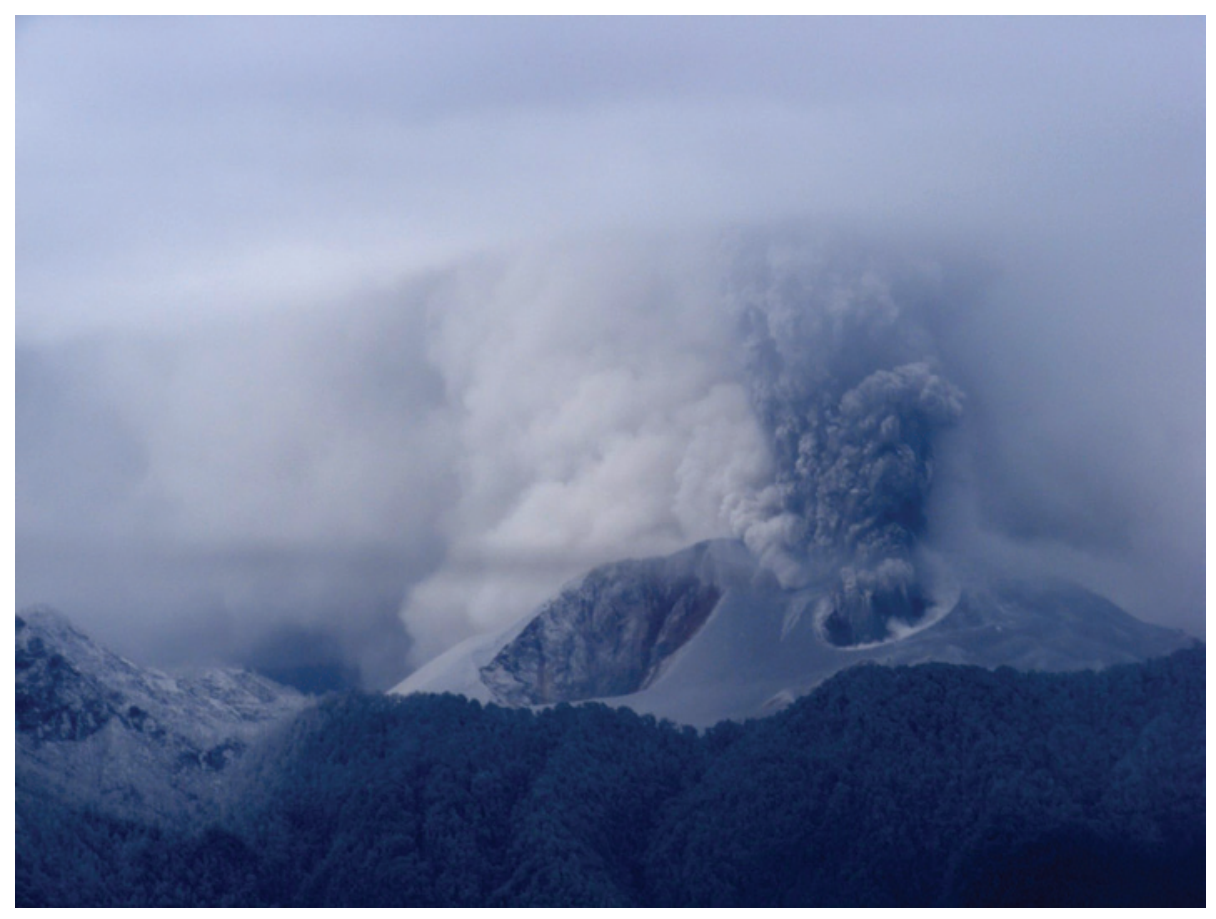

FIG. 18. Oblique aerial photograph of dual asymmetric vents that opened on the northern side of the old Chaiten lava dome at the onset of eruption. View is looking approximately southeast. SERNAGEOMIN photograph, 3 May 2008. 
they were also relatively low temperature. They likely formed when collapsing parts of the margin of a vertical eruption column(s) swept through the caldera and out the exit to East Breach Creek and possibly over the rim.

In contrast to the north and east sides of the volcano, high-concentration PDCs south of the volcano produced thick, unstratified, lithic-rich diamicts having characteristics of block-and-ashflow deposits. These PDCs were triggered by fragmentation from dome collapse rather than by explosively induced directionally focused currents or collapsing of vertical eruption columns. One locally preserved ash-and-lapilli deposit of ambiguous origin (Fig. 13, deposit 1) may be related to a small-volume PDC caused by column collapse during the explosive phase of eruption. The principal PDCs in the Chaitén River valley, however, were dominantly dense, ground-hugging flows rather than inflated, dilute flows. They did not scar or damage trees far above deposit surfaces, and they deposited thick, massive, poorly sorted, polymictic diamicts that filled the channel almost to the preserved flow limit. Trees were not charred during PDC passage. However, surfaces, and locally entire trunks, of large trees that were encased in meters-thick deposit were charred. Other vegetation buried by the deposits is both charred and uncharred. Analysis of wood charring by volcanic processes and forensic studies of fires suggest that flow temperatures may have been in the range of $150^{\circ}-300^{\circ} \mathrm{C}$ (e.g., Hudspith et al., 2010; www.tcforensic.com.au/docs/article10.html). Low-concentration ash clouds were associated with these block-and-ash flows, and with one exception, they, too, were of relatively low temperature.

The PDCs associated with the 2008-09 eruption of Chaitén Volcano are of comparable or smaller magnitude than PDCs associated with eruptions of smaller magnitude elsewhere, such as at Unzen, Sourfrière Hills Volcano, and Merapi (e.g., Fujii and Nakada, 1999; Cole et al., 2002; Charbonnier and Gertisser, 2011). Despite having a volcanic explosivity index value (Newhall and Self, 1982) VEI=4-5, the explosive phase of the eruption mainly produced widespread ashfall, and only minor PDCs, before shifting to a predominantly effusive phase that emplaced a nearly 500 million $\mathrm{m}^{3}$ rhyolite dome within a few months, and ultimately 800 million $\mathrm{m}^{3}$ by the end of the eruption in late 2009 (Pallister et al., 2010; 2013, this volume). Such behavior contrasts strikingly with that of the major rhyolitic eruption of the $20^{\text {th }}$ century-Katmai Volcano-in which extensive tephra fall and PDCs composed the bulk of the eruptive products, and effusive lava was a minor component of the total eruptive volume (Hildreth and Fierstein, 2000). At Chaitén, we interpret that a narrow eruption conduit, rapid and violent decompression of magma at very shallow level (Alfano et al., 2012), and high exit velocity (300-1,200 $\mathrm{ms}^{-1}$; Alfano et al., 2012) led to powerful explosions that produced tall eruption columns that favored production of widespread tephra fall rather than pyroclastic density currents. Other large (VEI 5-6) silicic Plinian eruptions that produced predominantly tephra fall and only minor, if any, PDCs occurred at Santa María Volcano, Guatemala, in 1902 (Williams and Self, 1983) and Quizapu Volcano, Chile, in 1932 (Hildreth and Drake, 1992).

Owing to their limited magnitude and extent, the PDCs associated with the eruption of Chaitén did not directly affect populace and infrastructure. Nevertheless, the dome-collapse PDC of February 2009 extended to within $3 \mathrm{~km}$ of the town of Chaitén, located only $10 \mathrm{~km}$ downvalley from the center of the caldera and partly repopulated following evacuation in May 2008. Pallister et al. (2013, this volume) estimate that as much as $10 \%$ of the new lava dome failed $(\sim 0.05$ $\mathrm{km}^{3}$ ) (Bernstein et al. (2013, this volume) estimate the failure was about $0.02 \mathrm{~km}^{3}$ ), and it failed on the west side of the dome complex approximately $90^{\circ}$ from the south outlet of the caldera. Our estimate of the PDC deposit volume in the valley $\left(0.003-0.005 \mathrm{~km}^{3}\right)$ suggests that at least $90 \%$ of the failed volume was trapped in the caldera moat. Had that dome collapse been larger, had a greater percentage of the consequent PDC escaped the caldera, had the collapse been more directly aligned with the exit through the south caldera wall, or had the explosive phase of the eruption produced large-volume column collapses, the town might have been directly affected by PDCs. Baxter $e t$ al. (2005) document the significant damage that can occur to villages close to volcanoes which are overrun by small-volume PDCs of the type that occurred at Chaitén. Despite a lack of direct impact to populace or infrastructure, the PDCs on the east and south sides of the volcano contributed significant amounts of sediment to river channels, and erosion of their deposits has had subsequent downstream impacts, especially in the Chaitén River valley. Therefore, even minor, areally restricted PDCs can have significant indirect impacts on vulnerable communities. 


\section{Conclusions}

Field investigations of deposit stratigraphy and sedimentology, vegetation disturbance, and sparse eyewitness observations reveal that multiple, smallmagnitude pyroclastic density currents (PDCs) having limited extents were associated with the 2008-09 eruption of Chaitén Volcano. Dilute, directionally focused density currents triggered during the early part of the explosive phase of eruption swept the north and northeast sides of the volcano. These PDCs were highly mobile and energetic, sweeping over the 200-meter-tall caldera wall and felling trees as far as $2 \mathrm{~km}$ distance in two distinct patches having areas of about $4 \mathrm{~km}^{2}$ and $2 \mathrm{~km}^{2}$, respectively. Examination of the deposit and vegetation disturbance north of the volcano indicates the current on that flank had, to first approximation, a minimum dynamic pressure of 2-4 $\mathrm{kPa}$, a minimum near-ground velocity of $30-40 \mathrm{~ms}^{-1}$, and a relatively low temperature $\left(<200^{\circ} \mathrm{C}\right)$. The roughly 30 -cm-thick bipartite deposit of that PDC, having a strongly fines-depleted, pumice-and-lithic ash-and-lapilli lower facies locally mixed with substrate debris and an upper facies of fines-enriched, pumice-and-lithic ash, is similar to deposits described from directed-blast-generated PDCs. The directionally focused PDCs were produced by rapid decompression of a very shallowly emplaced magma when two vents opened through the old lava dome. Directionality of the PDCs was influenced by vent morphologies leading to tilting of the eruption column or along fissures that were oriented subvertically, and not by a mass failure of the old lava dome or the volcano's flank.

Dilute, low-temperature PDCs that exited the caldera over a low point on the east-southeast caldera rim during the explosive phase of eruption were less energetic and felled only small understory vegetation between 0.7 and $3 \mathrm{~km}$ from the caldera rim. Deposits of those PDCs are composed of curviplanar, finely stratified beds of pumice-and-lithic ash and lapilli. On the basis of forest disturbance and deposit characteristics, we suggest that those PDCs formed during one or more of the sustained vertical eruptions as margins of the eruption columns collapsed and produced small-volume, dilute, lowtemperature currents.

In contrast to PDCs on the north and east sides of the volcano, two principal PDCs entering the Chaitén River valley south of the volcano through a gap in the caldera rim were caused by partial collapses of the new lava dome that grew subsequent to the explosive phase of eruption. Those PDCs produced several-meter-thick, unsorted and unstratified, lithicrich diamicts characteristic of dense, concentrated block-and-ash flows. They were funneled along a tributary leading from the main breach in the caldera rim and then spread along the middle to lower reaches of the Chaitén River valley. Those flows were incapable of charring vegetation except where it was deeply buried, suggesting the PDCs were of moderate temperature $\left(<300^{\circ} \mathrm{C}\right)$. A PDC caused by partial collapse of the lava dome on 19 February 2009 produced the thickest, hottest, and most extensive primary flow deposit in the Chaitén River valley. That PDC traveled $6 \mathrm{~km}$ beyond the caldera rim and came within $3 \mathrm{~km}$ of the town of Chaitén.

PDCs associated with the eruption of Chaitén Volcano were comparable to or smaller than PDCs associated with smaller magnitude $(<\mathrm{VEI} 4)$ eruptions at other volcanoes. Although the Chaitén PDCs were of limited magnitude and extent and did not directly affect populace or infrastructure, they did have significant indirect impact on a vulnerable community. The PDCs contributed significant sediment loads to river channels, which subsequently had downstream impacts especially along the Chaitén River valley, and reworking of PDC deposits on the north side of the volcano disrupted Route 7, the national highway north of the volcano.

\section{Acknowledgments}

Discussions with several colleagues during and subsequent to our initial field campaign stimulated and focused our thinking about the events that transpired at Chaiten. Thought-provoking discussions with J. Pallister (United States Geological Survey), F. Swanson (United States Forest Service), and J. Eichelberger (United States Geological Survey) sharpened our interpretations of events. L. Lara (SERNAGEOMIN) provided invaluable assistance gathering information about the video footage shot by Aerotaxis del Sur. D. Guzmán (Parque Pumalín) kindly provided and permitted use of his photographs of the 19 February 2009 pyroclastic density current. J. Eichelberger got the project started with seed money that allowed those of us from USGS to visit Chaitén. We thank B. Brand (Boise State University), E. Calder (SUNY Buffalo), R. Watts (University of The West Indies), and F. Swanson for reviews and comments that sharpened our presentation. 


\section{References}

Abdurachman, E.K.; Bourdier, J.-L.; Voight, B. 2000. Nuées ardentes of 22 November 1994 at Merapi Volcano, Java, Indonesia. Journal of Volcanology and Geothermal Research 100 (1-4): 345-361.

Alfano, F.; Bonadonna, C.; Gurioli, L. 2012. Insights into eruption dynamics from textural analysis: the case of the May, 2008, Chaitén eruption. Bulletin of Volcanology 74 (9): 2095-2108. doi 10.1007/s00445-012-0648-3.

Alfano, F.; Bonadonna, C.; Volentik, A.C.M.; Connor, C.B.; Watt, S.F.L.; Pyle, D.M.; Connor, L.J. 2011. Tephra stratigraphy and eruptive volume of the May, 2008, Chaitén eruption, Chile. Bulletin of Volcanology 73 (5): 613-630.

Alvarado, G.E.; Soto, G.J.; Schminke, H-U.; Bolge, L.L.; Sumita, M. 2006. The 1968 andesitic lateral blast eruption at Arenal Volcano, Costa Rica. Journal of Volcanology and Geothermal Research 157: 9-33.

Bacon, C.R. 1983. Eruptive history of Mount Mazama and Crater Lake caldera, Cascade Range, U.S.A. Journal of Volcanology and Geothermal Research 18: 57-115.

Basualto, D.; Peña, P.; Delgado, C.; Moreno, H.; Muñoz, J.O. 2008. Seismic activity related to the evolution of the explosive eruption of Chaitén Volcano in the Southern Andes Volcanic Zone. Eos, Transactions of the American Geophysical Union 89 (53), Fall Meeting Supplement, Abstract V43D-2178. San Francisco.

Baxter, P.J.; Boyle, R.; Cole, P.; Neri, A.; Spence, R.; Zuccaro, G. 2005. The impacts of pyroclastic surges on buildings at the eruption of the the Soufrière Hills Volcano, Montserrat. Bulletin of Volcanology 67: 292-313.

Belousov, A.; Voight, B.; Belousova, M. 2007. Directed blasts and blast-generated pyroclastic density currents: a comparison of the Bezymianny 1956, Mount St. Helens 1980, and Soufrière Hills, Montserrat 1997 eruptions and deposits. Bulletin of Volcanology 69: 701-740.

Belousova, M.; Belousov, A.; Patia, H.; Hoblitt, R.P. 2011. The January 21, 1951 blast of Mount Lamington in Papua New Guinea: sequence of events and characteristics of deposits. American Geophysical Union Fall Meeting, San Francisco, CA, 5-9 December, Abstract V51F-2567.

Bernstein, M.; Pavez, A.; Varley, N.; Whelley, P.; Calder, E. 2013. Rhyolite lava dome growth styles at Chaitén Volcano, Chile (2008-2009): Interpretation of thermal imagery. Andean Geology 40 (2): 295-309.
Blong, R.J. 1984. Volcanic hazards: A sourcebook on the effects of eruptions. Academic Press: 424 p. Sydney.

Branney, M.J.; Kokelaar, P. 2002. Pyroclastic Density Currents and the Sedimentation of Ignimbrites. Geological Society, London, Memoir 27: 143 p.

Brown, R.J.; Branney, M.J.; Maher, C.; Dávila-Harris, P. 2010. Origin of accretionary lapilli within groundhugging density currents: evidence from pyroclastic couplets on Tenerife. Geological Society of America Bulletin 122: 305-320.

Bryden, K.M.; Ragland, K.W.; Rutland, C.J. 2002. Modeling thermally thick pyrolysis of wood. Biomass and Bioenergy 22: 41-53.

Byrne, K.E.; Mitchell, S.J. 2007. Overturning resistance of western red cedar and western hemlock in mixed species stands in coastal British Columbia. Canadian Journal of Forest Research 37: 931-939.

Carn, S.A.; Pallister, J.S.; Lara, L.; Ewert, J.W.; Watt, S.; Prata, A.J.; Thomas, R.J.; Villarosa, G. 2009. The unexpected awakening of Chaitén Volcano, Chile. Eos, Transactions of the American Geophysical Union 90 (24): 205-206.

Castro, J.M.; Cordonnier, B.; Tuffen, H.; Tobin, M.J.; Puskar, L.; Martin, M.C.; Bechtel, H.A. 2012. The role of melt-fracture degassing in defusing explosive rhyolite eruptions at volcán Chaitén. Earth and Planetary Science Letters 333-334: 63-69.

Castro, J.M.; Dingwell, D.B. 2009. Rapid ascent of rhyolitic magma at Chaitén Volcano, Chile. Nature 461: 780-783.

Charbonnier, S.J.; Gertisser, R. 2011. Deposit architecture and dynamics of the 2006 block-and-ash flows of Merapi Volcano, Java, Indonesia. Sedimentology 58: 1573-1612.

Clarke, A.B.; Voight, B. 2000. Pyroclastic current dynamic pressure from aerodynamics of tree or pole blow-down. Journal of Volcanology and Geothermal Research 100 (1-4): 395-412.

Cole, P.D.; Calder, E.S.; Sparks, R.S.J.; Clarke, A.B.; Druitt, T.H.; Young, S.R.; Herd, R.A.; Harford, C.L.; Norton, G.E. 2002. Deposits from dome-collapse and fountain-collapse pyroclastic flows at Soufrière Hills Volcano, Montserrat. In The Eruption of Soufrière Hills Volcano, Montserrat, from 1995-1999 (Druitt, T.H.; Kokelaar, B.P.; editors). Geological Society, London, Memoir 21: 231-262.

Cole, P.D.; Fernández, E.; Duarte, E.; Duncan, A.M. 2005. Explosive activity and generation mechanisms of pyroclastic flows at Arenal Volcano, Costa Rica, between 1987 and 2001. Bulletin of Volcanology 67: 695-716. 
Costa, J.E. 1984. Physical geomorphology of debris flows. In Developments and Applications of Geomorphology (Costa, J.E.; Fleisher, P.J.; editors). Springer, Heidelberg: 268-317.

Élie, J.-G.; Ruel, J.-C. 2005. Windthrow hazard modeling in boreal forests of black spruce and jack pine. Canadian Journal of Forest Research 35: 2655-2663.

Folch, A.; Jorba, O.; Viramonte, J. 2008. Volcanic ash forecast-application to the May 2008 Chaitén eruption. Natural Hazards Earth System Science 8: 927-940.

Folk, R.L. 1980. Petrology of Sedimentary Rocks. Hemphill Publishing Company: 182 p. Austin.

Fujii, T.; Nakada, S. 1999. The 15 September 1991 pyroclastic flows at Unzen Volcano (Japan)-a flow model for associated ash-cloud surges. Journal of Volcanology and Geothermal Research 89: 159-172.

Garcia, O.; Marti, J.; Aguirre, G.; Geyer, A.; Iribarren, I. 2011. Pyroclastic density currents from Teide-Pico Viejo (Tenerife, Canary Islands)-implications for hazard assessment. Terra Nova 23: 220-224.

Grønli, M.G.; Melaaen, M. 2000. Mathematical model for wood pyrolysis-comparison of experimental measurements with model predictions. Energy and Fuels 14: 791-800.

Hildreth, W.; Drake, R.E. 1992. Volcán Quizapu, Chilean Andes. Bulletin of Volcanology 54: 93-125.

Hildreth, W.; Fierstein, J. 2000. Katmai volcanic cluster and the great eruption of 1912. Geological Society of America Bulletin 112: 1594-1620.

Hoblitt, R.P. 1996. Direct temperature measurements of deposits, Mount St. Helens, Washington, 1980-1981. United States Geological Survey Professional Paper 1387: $76 \mathrm{p}$.

Hoblitt, R.P. 2000. Was the 18 May 1980 lateral blast at Mount St. Helens the product of two explosions? Philosophical Transactions of the Royal Society of London, Series A: Mathematical, Physical, and Engineering Sciences 358 (1770): 1639-1661.

Hoblitt, R.P.; Miller, C.D.; Vallance, J.W. 1981. Origin and stratigraphy of the deposit produced by the May 18 directed blast. In The 1980 Eruptions of Mount St. Helens, Washington (Lipman, P.W.; Mullineaux, D.R.; editors). United States Geological Survey Professional Paper 1250: 401-419.

Hoblitt, R.P.; Wolfe, E.W.; Scott, W.E.; Couchman, M.R.; Pallister, J.S.; Javier, D. 1996. The preclimactic eruptions, June 1991, Mount Pinatubo, Philippines. In Fire and Mud: Eruptions and Lahars of Mount Pinatubo, Philippines (Newhall, C.G.; Punongbayan, R.S.; editors).
Philippine Institute of Volcanology and Seismology, Quezon City and University of Washington Press, Seattle: 457-511.

Hudspith, V.A.; Scott, A.C.; Wilson, C.J.N.; Collinson, M.E. 2010. Charring of woods by volcanic processesan example from the Taupo ignimbrite, New Zealand. Palaeogeography, Palaeoclimatology, Palaeoecology 291: 40-51.

Kelfoun, K.; Legros, F.; Gourgaud, A. 2000. A statistical study of trees damaged by the 22 November 1994 eruption of Merapi Volcano (Java, Indonesia)-relationships between ash-cloud surges and block-and-ash flows. Journal of Volcanology and Geothermal Research 100: 379-393.

Lagmay, M.A.; Pyle, D.M.; Dade, B.; Oppenheimer, C. 1999. Control of crater morphology on flow path direction of Soufrière-type pyroclastic flows. Journal of Geophysical Research B104 (4): 7169-7181.

Lara, L.E. 2009. The 2008 eruption of the Chaitén Volcano, Chile-a preliminary report. Andean Geology 36 (1): 125-129.

Loughlin, S.C.; Calder, E.S.; Clarke, A.; Cole, P.D.; Luckett, R.; Mangan, M.T.; Pyle, D.M.; Sparks, R.S.J.; Voight, B.; Watts, R.B. 2002. Pyroclastic flows and surges generated by the 25 June 1997 dome collapse, Soufrière Hills Volcano, Montserrat. In The Eruption of Soufrière Hills Volcano, Montserrat, from 1995-1999 (Druitt, T.H.; Kokelaar, B.P.; editors). Geological Society, London, Memoir 21: 191-209.

Major, J.J.; Lara, L.E. 2013. Overview of Chaitén Volcano, Chile, and its 2008-2009 eruption. Andean Geology 40 (2): 196-215.

Miyabuchi, Y. 1999. Deposits associated with the 1990-1995 eruption of Unzen Volcano, Japan. Journal of Volcanology and Geothermal Research 84: 139-158.

Moore, J.G.; Sisson, T.W. 1981. Deposits and effects of the May 18 pyroclastic surge. In The 1980 Eruptions of Mount St. Helens, Washington (Lipman, P.W.; Mullineaux, D.R.; editors). United States Geological Survey Professional Paper 1250: 421-438.

Newhall, C.G.; Self, S. 1982. The volcanic explosivity index (VEI)-an estimate of explosive magnitude for historical volcanism. Journal of Geophysical Research 87 (C2): 1231-1238.

Nicoll, B.C.; Gardiner, B.A.; Rayner, B.; Peace, A.J. 2006. Anchorage of coniferous trees in relation to species, soil type, and rooting depth. Canadian Journal of Forest Research 36: 1871-1883. 
Pallister, J.S.; Major, J.J.; Pierson, T.C.; Hoblitt, R.P.; Lowenstern, J.B.; Eichelberger, J.C.; Lara, L.; Moreno, H.; Muñoz, J.; Castro, J.M.; Iroumé, A.; Andreoli, A.; Jones, J.; Swanson, F.; Crisafulli, C. 2010. Interdisciplinary studies of eruption at Chaitén Volcano, Chile. Eos, Transactions of the American Geophysical Union 91 (42): 381-382.

Pallister, J.S.; Diefenbach, A.; Burton, W.; Muñoz, J.; Griswold, J.; Lara, L.; Lowenstern, J.; Valenzuela, C. 2013. The Chaitén rhyolite lava dome: Eruption sequence, lava dome volumes, rapid effusion rates and source of the rhyolite magma. Andean Geology 40 (2): 277-294.

Pierson, T.C.; Major, J.J.; Amigo, A.; Moreno, H. 2013. Acute sedimentation response to rainfall following the explosive phase of the 2008-09 eruption of Chaitén Volcano, Chile. Bulletin of Volcanology 75, 723: 17 p. doi 10.1007/s00445-013-0723-4.

Ritchie, L.J.; Cole, P.D.; Sparks, R.S.J. 2002. Sedimentology of deposits from the pyroclastic density current of 26 December 1997 at Soufrière Hills Volcano, Montserrat. In The Eruption of Soufrière Hills Volcano, Montserrat, from 1995-1999 (Druitt, T.H.; Kokelaar, B.P.; editors). Geological Society, London, Memoir 21: 435-456.

Sarocchi, D.; Sulpizio, R.; Macias, J.L.; Saucedo, R. 2011. The 17 July 1999 block-and-ash flow (BAF) at Colima Volcano-new insights on volcanic granular flows from extended textural analysis. Journal of Volcanology and Geothermal Research 204: 40-56.

Scott, A.C.; Sparks, R.S.J.; Bull, I.D.; Knicker, H.; Evershed, R.P. 2008. Temperature proxy data and their significance for the understanding of pyroclastic density currents. Geology 36: 143-146.

SERNAGEOMIN. 2008a. Erupción del volcán Chaitén, Primer Informe Técnico, 03 de mayo de 2008: 7 p.

SERNAGEOMIN. 2008b. Erupción del volcán Chaitén, Cuarto Informe Técnico, 08 de mayo de 2008: 4 p.

SERNAGEOMIN. 2008c. Erupción del volcán Chaitén, Octavo Informe Técnico, 12 de mayo de 2008: 4 p.

SERNAGEOMIN. 2008d. Erupción del volcán Chaitén, Décimo Segundo Informe Técnico, 21 de mayo de 2008: 4 p.

SERNAGEOMIN. 2008e. Erupción del volcán Chaitén, Cuadragésimo Segundo Informe Técnico, 24 de Julio de 2008: 3 p.

Sigurdsson, H.; Carey, S.N.; Espindola, J.M. 1984. The 1982 eruptions of El Chichón Volcano, Mexico-stratigraphy of pyroclastic deposits. Journal of Volcanology and Geothermal Research 23: 11-37.
Sim, S.; Ogden, D.E. 2012. Effects of vent asymmetry on explosive eruptions. American Geophysical Union Fall Meeting, San Francisco, CA, 3-7 December, Abstract V41B-2791.

Sparks, R.S.J.; Barclay, J.; Calder, E.S.; Herd, R.A.; Komorowski, J.-C.; Luckett, R.; Norton, G.E.; Ritchie, L.J.; Voight, B.; Woods, A.W. 2002. Generation of a debris avalanche and violent pyroclastic density current on 26 December (Boxing Day) 1997 at Soufrière Hills Volcano, Montserrat. In The Eruption of Soufrière Hills Volcano, Montserrat, from 1995-1999 (Druitt, T.H.; Kokelaar, B.P.; editors). Geological Society, London, Memoir 21: 409-434.

Swanson, F.J.; Jones, J.A.; Crisafulli, C.; Lara, A. 2013. Effects of volcanic and hydrologic processes on forest vegetation, Chaitén Volcano, Chile. Andean Geology 40 (2): 359-391.

Tanguy, J. 1994. The 1902-1905 eruptions of Montagne Pelée, Martinique-anatomy and retrospection. Journal of Volcanology and Geothermal Research 60: 87-107.

Taylor, G.A.M. 1958. The 1951 eruption of Mount Lamington, Papua. Australia Bureau of Mineral Resources, Geology and Geophysics Bulletin 38: $129 \mathrm{p}$.

Valentine, G.A. 1998. Damage to structures by pyroclastic flows and surges, inferred from nuclear weapons effects. Journal of Volcanology and Geothermal Research 87: 117-140.

Voight, B.; Davis, M.J. 2000. Emplacement temperatures of the November 22, 1994 nuée ardente deposits, Merapi Volcano, Java. Journal of Volcanology and Geothermal Research 100: 371-377.

Waitt, Jr., R.B. 1981. Devastating pyroclastic density flow and attendant airfall of May 18-stratigraphy and sedimentology of deposits. In The 1980 Eruptions of Mount St. Helens, Washington (Lipman, P.W.; Mullineaux, D.R.; editors). United States Geological Survey Professional Paper 1250: 439-458.

Walker, G.P.L. 1980. The Taupo pumice: product of the most powerful known (ultraplinian) eruption. Journal of Volcanology and Geothermal Research 8: 69-94.

White, J.D.L.; Houghton, B.F. 2006. Primary volcaniclastic rocks. Geology 34: 677-680.

Williams, S.N.; Self, S. 1983. The October 1902 Plinian eruption of Santa Maria Volcano, Guatemala. Journal of Volcanology and Geothermal Research 16: 33-56.

Wilson, C.J.N. 1985. The Taupo eruption, New Zealand-II, The Taupo ignimbrite. Philosophical Transactions of 
the Royal Society of London, Series A, Mathematical and Physical Sciences 314 (1529): 229-310.

Winner, W.E.; Casadevall, T.J. 1981. Fir leaves as thermometers during the May 18 eruption. In The
1980 Eruptions of Mount St. Helens, Washington (Lipman, P.W.; Mullineaux, D.R.; editors). United States Geological Survey Professional Paper 1250: 315-320.

Manuscript received: June 25, 2012; revised/accepted: January 29, 2013; available online: February 01, 2013. 